\title{
NORM CONFLICT IN INTERNATIONAL LAW: WHITHER HUMAN RIGHTS?
}

\author{
MARKO MILANOVIĆ* \\ INTRODUCTION
}

Two incontestable features of modern international law - the multiplicity of its law-making processes and the ever-increasing variety of the subject-matter that it seeks to regulate - have one invariable consequence: the increasing likelihood of norm conflict, part of the phenomenon of fragmentation of international law. Much work has been devoted to this topic, and, as is well known, it has already been the object of a comprehensive study by the International Law Commission (ILC). ${ }^{1}$

Unlike much of the theoretical work on the subject, this article attempts to deal with the practicalities of norm conflict. Like the ILC Study, it will try to further develop the toolbox that judges and lawyers have at their disposal when dealing with cases involving a collision of norms. ${ }^{2}$ It will do so by focusing on situations in which one of the conflicting rules is a rule of human rights law, and, more specifically, on those norm conflicts in which some other international rule, for instance a UN Security Council resolution, attempts to prevail over or is at the very least equal to a human rights norm. Such cases of norm conflict are becoming more and more frequent and deal with matters of great political importance, such as the targeted sanctions against or the preventative detention of suspected terrorists.

There are several other reasons for this emphasis on human rights. First, human rights norms operate not only between states, but also between

Copyright (C 2009 by Marko Milanović.

* LL.B (Belgrade), LL.M (Michigan), PhD candidate (Cambridge); Associate, Belgrade Centre for Human Rights, formerly law clerk to Judge Thomas Buergenthal, International Court of Justice. E-mail: mm676@cam.ac.uk. I would like to thank Jean d'Aspremont, Vera Gowlland-Debbas, Conor McCarthy, Francesco Messineo, Vladimir Pavlović, Tobias Thienel, Isabelle Van Damme and Michael Wood, as well as all participants at the forum at the Third Biennial Conference of the European Society of International Law, held in Heidelberg in September 2008, where this paper was first presented, for their most helpful comments. All errors remain my own.

1. Int'1 L. Comm'n [ILC], Fragmentation of International Law: Difficulties Arising from the Diversification and Expansion of International Law, UN Doc. A/CN.4/L.682 (Apr. 13, 2006) (finalized by Martti Koskenniemi) [hereinafter ILC Study].

2. See id. para. 20. 
states and individuals. This does not mean that human rights law is not about inter-state obligations, but that it is not reducible to synallagmatic bargains between states. ${ }^{3}$ Second, because of the community interest and values that human rights norms enshrine, norm conflict situations involving human rights are, as we shall see, frequently considered to be of constitutional importance, even though human rights norms are per se not hierarchically superior to other norms of international law. These conflicts inspire the use of the language of constitutionalism - very fashionable these days ${ }^{4}$ - which can be observed in most of the cases that we will examine. Third, a focus on human rights is useful since, for public international lawyers, human rights (and human rights lawyers) are one of the principal culprits of fragmentation..$^{5}$ To the generalist, the human rights lawyer's ${ }^{6}$ misguided belief that wishful thinking is a law-making process and tendency toward what Alain Pellet calls droit de l'hommisme lead him to assert that the special nature of human rights somehow warrants deviations from general international law. ${ }^{7}$ From a generalist perspective, the human rightist penchant for special solutions is deeply troubling, since it disrupts the systemic quality of general international law. Human rights norm conflicts thus expose not only the various constitutionalist agendas and projects, but also the universalist agenda espoused by general international lawyers.

As stated above, this article will examine those normative conflicts where a putatively hierarchically superior norm attempts to override or prevail over a conflicting human rights norm. Both in practice and in the literature, the posture is usually the other way around - it is human rights

3. See generally James Crawford, Multilateral Rights and Obligations in International Law, 319 RECUEIL DES COURS 325 (2006); Bruno Simma, From Bilateralism to Community Interest in International Law, 250 RECUEIL DES COURS 217 (1994); Bruno Simma, International Human Rights and General International Law: A Comparative Analysis, IV-2 COLLECTED COURSES OF THE ACAD. OF EUR. LAW 153 (1993).

4. Sir Michael Wood, The Hersch Lauterpacht Memorial Lectures: The UN Security Council and International Law, First Lecture: The Legal Framework of the Security Council para. 17 (Nov. 7, 2006), available at http://www.lcil.cam.ac.uk/Media/lectures/pdf/2006_hersch_lecture_1.pdf.

5. See Martti Koskenniemi \& Päivi Leino, Fragmentation of International Law? Postmodern Anxieties, 15 LEIDEN J. InT'L L. 553, 567-70 (2002). See also Arnold N. Pronto, 'Human-Rightism' and the Development of General International Law, 20 LEIDEN J. INT'L L. 753 (2007) (arguing that international human rights norms are increasingly "mainstreamed" into general international law).

6. Labels such as "generalists," "human rights lawyers" or "European lawyers" are nothing more than very broad generalizations, and are used in this article simply as convenient shorthand.

7. Koskenniemi \& Leino, supra note 5, at 569. Two prominent examples are the various arguments put forward in favor of special rules for reservations and succession to human rights treaties. See, e.g., Menno Kamminga, State Succession in Respect of Human Rights Treaties, 7 EuR. J. InT'L L. 469 (1996); RESERVATIONS TO Human Rights TREATIES AND THE VienNA CONVENTION REgime: CONFLICT, HARMONY OR RECONCILIATION (Ineta Ziemele ed., 2004). 
that (supposedly) override other rules, not vice versa. One concept in particular is often invoked in that regard, especially by scholars - jus cogens, the body of peremptory norms of international law, most of which deal with human rights. ${ }^{8}$

However, even a casual survey of the jurisprudence would show that jus cogens is used rarely, if ever, to invalidate supposedly conflicting norms. On the contrary, courts generally exhibit a tendency to do what they can to avoid norm conflicts. To my knowledge there is perhaps only one, rightfully much-maligned case ${ }^{9}$ where jus cogens was successfully invoked to resolve a norm conflict, ${ }^{10}$ and even in that case it is not entirely clear whether it was decided on norm conflict grounds. ${ }^{11}$ Hence, as Ian Brownlie famously put it, jus cogens is like a car which has never left the garage. ${ }^{12}$ It much more frequently figures as a rhetorical device or as a 'weapon of deterrence, $^{13}$ an incentive to courts to avoid a conflict through

8. For perhaps the most far-reaching example, see ALEXANDER ORAKHELASHVILI, PEREMPTORY NORMS IN INTERNATIONAL LAW (2006). To the present author, at least, Prosper Weil's warning against "seeking to create today the law of tomorrow's international society" is as cogent as ever. Prosper Weil, Towards Relative Normativity in International Law?, 77 AM. J. INT’L L. 413, 442 (1983).

9. See Judicial Decisions, 14 ITALIAN Y. B. INT'L L. 341, 341 (2004) (providing relevant text of Ferrini v. Federal Republic of Germany, Cass., sez. un., 11 mar. 2004, n.5044). For analysis of the decision, see Pasquale De Sena \& Francesca De Vittor, State Immunity and Human Rights: the Italian Supreme Court Decision on the Ferrini Case, 16 EuR. J. INT'L L. 89 (2005); Andrea Gattini, War Crimes and State Immunity in the Ferrini Decision, 3 J. INT'L CRIM. JuST. 224 (2005).

10. The case that is most often cited as using jus cogens as a rule of norm conflict resolution is the House of Lords decision in Regina v. Bow Street Metropolitan Stipendiary Magistrate, Ex parte Pinochet Ugarte (No 3), [2000] 1 A.C. 147 (H.L. 1999) (U.K.). For example, even the ILC states that in that case "for the first time a local domestic court denied immunity to a former Head of State on the grounds that there cannot be any immunity against prosecution for breach of jus cogens." ILC Study, supra note 1, para. 371. However, though the reasoning of the seriatim opinions of their Lordships in Pinochet is notoriously difficult to decipher, the holding of the House was emphatically not that jus cogens invalidated any conflicting rules on state immunity. This is confirmed, inter alia, by their Lordships' decision in Jones v. Ministry of Interior of Saudi Arabia, [2006] UKHL 26, [2007] 1 A.C. 270, 298 (appeal taken from Eng.), where they interpreted Pinochet as holding that the Convention against Torture waived or created an exception to immunities ratione materiae for the crime of torture. Jus cogens had precisely nothing to do with it. See also Al-Adsani v. United Kingdom, App. No. 35763/97, Eur. Ct. H.R. (21 November 2001), available through HUDOC database at http:// www.echr.coe.int/echr/en/hudoc (holding by 9 votes to 8 that the jus cogens prohibition of torture did not conflict with the law of state immunity).

11. See Andrea Bianchi, Human Rights and the Magic of Jus Cogens, 19 EuR. J. INT'L L. 491, 500-01 (2008) (arguing that Ferrini was decided on a wider notion of international public order).

12. Change and Stability in International Law-Making 175 (Antonio Cassese \& Joseph H. H. Weiler eds., 1988).

13. Prosper Weil, Le droit international en quête de son identité, 237 RECUEIL DES COURS 9, 278 (1992-VI) (referring to jus cogens as "an arme de dissuasion - l'arme nucléaire, en quelque sorte, du système international.”) 
interpretation, instead of resolve it on the basis of normative hierarchy. ${ }^{14}$ Thus, as we will see, with regard to conflict resolution based on hierarchy, Article 103 of the United Nations Charter, stipulating the primacy of state obligations under the Charter over their other international obligations, is of much greater practical relevance.

This article is organized as follows. Part I will briefly outline the analytical framework from which the rest of the study will proceed. Part II will address Article 103 of the Charter as a rule of conflict resolution and the recent relevant case law of the European Court of Human Rights, the House of Lords, and the courts of the European Union. Part III will then examine how norm conflicts test some of the basic assumptions about what exactly constitutes an autonomous legal order. The final part concludes.

\section{DEFINITIONS AND ANALYTICAL FRAMEWORK}

The analysis in the following sections of this article must necessarily start from a working framework, which will be explained and defended here as much as space allows. What first needs to be defined is the very notion of a conflict of norms, norms themselves being seen as legally binding rules establishing certain rights and obligations between subjects of international law. The notion of conflict will be defined broadly: a relationship of conflict exists between two norms "if one norm constitutes, has led to, or may lead to, a breach of the other."

It is possible to adopt a narrower conception of conflict as concerning only those situations in which a state would be bound by two contradictory obligations, and not those situations in which one norm sets out an obligation while the other sets out a right of the state. According to some authors, this latter scenario does not qualify as a proper norm conflict, since the state can choose not to exercise its right pursuant to one norm, and thus

14. There are several reasons why this is so. Most importantly, jus cogens is a blunt instrument. Its sanction is drastic: the invalidation of the conflicting norm. If this norm is contained in a treaty, the sanction is even worse: the whole treaty goes, even if the impugned norm is only a very small part thereof. See Vienna Convention on the Law of Treaties, arts. 53, 64, May 23, 1969, 1155 U.N.T.S. 331, 8 I.L.M. 679 [hereinafter VCLT]. Furthermore, not only is the sanction of jus cogens drastic, but it also limits the type of arguments than can be made in resolving the conflict. As soon as it is established that norm X has the status of jus cogens and conflicts with norm Y, all discussions are over. There can be no balancing of interests, no competing considerations than can be put forward. Witness, for example, how one advocate of a broad use of jus cogens sees the matter: "there is no scientific or intellectual value in attempts to influence the hierarchy of norms debate by invoking the hypothetical risks [of prejudice to the cooperation between states if sovereign immunity is denied] examined above. The issue of hierarchy of norms is an issue of legal science." Alexander Orakhelashvili, State Immunity and Hierarchy of Norms: Why the House of Lords Got It Wrong, 18 EUR. J. INT'L L. 955, 957 (2007).

15. Joost Pauwelyn, Conflict of Norms in Public InTERnational Law: How WTO LaW RELATES TO OTHER RULES OF INTERNATIONAL LAW 175-76 (2003). 
comply with its obligation from the other, while in the case of two conflicting obligations the state has no choice but to breach one of its obligations. $^{16}$

However, as well explained by Pauwelyn, ${ }^{17}$ this rigid approach mistakes one possible solution for a norm conflict - the fact that it can to an extent be avoided - with the actual existence of the conflict. Forcing the state to refrain from exercising one of its rights could thus lead to the frustration of the permissive norm equally as with an obligatory one. Therefore, the conception of conflict adopted in this article will be a wide one, encompassing not only cases of incompatibility of two obligations, but also conflicts between obligations and permissive norms.

A further distinction that must be made is between apparent and genuine norm conflicts, and consequently between conflict avoidance on the one hand, and conflict resolution on the other. An apparent conflict is one where the content of the two norms is at first glance contradictory, yet the conflict can be avoided, most often by interpretative means. There is a powerful tendency in international law toward harmonization and systemic integration that abhors conflicts and seeks to avoid them. Presumptions against conflict and techniques of harmonious interpretation are thus often used by courts, explicitly ${ }^{18}$ or implicitly. ${ }^{19}$

Yet there are instances in which all techniques of conflict avoidance will fail, and a genuine, as opposed to an apparent, conflict will emerge. ${ }^{20}$ These true norm conflicts are those that cannot be avoided, but which it might be possible to resolve. Unlike avoidance, which interprets away any incompatibility, resolution requires one conflicting norm to prevail or have priority over another. Moreover, for a genuine conflict to be truly resolved it is necessary not only for one norm to have priority, but also for the wrongfulness on the part of the state for failing to abide by the displaced norm to be precluded as a matter of state responsibility. It is only if the

16. See C. Wilfred Jenks, Conflict of Law-Making Treaties, 30 BRIT. Y.B. INT’L L. 401 (1953).

17. See PAUWELYN, supra note 15, at 184-88 (identifying different types of conflict situations). See also ILC Study, supra note 1, para. 24 (noting both the basic and looser understandings of incompatibility in norm conflicts); Erich Vranes, The Definition of 'Norm Conflict' in International Law and Legal Theory, 17 EUR. J. INT'L L. 395 (2006) (arguing that the narrow definition of "norm conflict" is insufficient in legal theory).

18. See, e.g., Al-Adsani v. United Kingdom, App. No. 357/63/97, Eur. Ct. H.R. para. 55 (21 November 2001), available through the HUDOC database at http://www.echr.coe.int/echr/en/hudoc ("The Convention should so far as possible be interpreted in harmony with other rules of international law of which it forms part, including those relating to the grant of State immunity.").

19. See ILC Study, supra note 1, para. 37; PAUWELYN, supra note 15, at 240-44.

20. See PAUWELYN, supra note 15, at 272 ("Interpretation may solve apparent conflicts; it cannot solve genuine conflicts."). 
state bears no legal cost for disregarding one of its commitments in favor of another that a norm conflict has truly been resolved.

Crucially, international law lacks the key method for resolving genuine norm conflict that is used in domestic law: a centralized system with a developed hierarchy, and at that a hierarchy based on the sources of norms. ${ }^{21}$ Thus, in domestic systems a constitutional norm will prevail over a statutory one, ${ }^{22}$ while legislation will ordinarily prevail over executive orders or decrees. Not so in international law, where all sources of law are generally considered equal. ${ }^{23}$ Though a treaty will usually prevail over custom, this is so only because the customary rule is jus dispositivum, meaning that it can be contracted out of, and applies only by default if the parties in question have not agreed differently. ${ }^{24}$ But the treaty is also jus dispositivum, and can equally be amended or abrogated by subsequent treaty or custom. In international law, the only true instances of hierarchy are the very limited number of norms of jus cogens, such as the prohibition of genocide or the prohibition of torture. Such norms invalidate any other conflicting norm, though, as we have seen above, such invalidation rarely, if ever, happens in practice, and can only be superseded by a subsequent norm of equal status. ${ }^{25}$

Moreover, domestic legal systems are centralized in the sense that even in domestic systems with plural legislators, such as federations, there are predetermined rules about the supremacy of norms passed by these different legislators. In the United States, for example, the Supremacy Clause of the Constitution provides that the Constitution itself and any law made in pursuance thereof shall prevail over contrary state law. ${ }^{26}$ United States courts have developed an exceptionally complex federalism jurisprudence, whose main purpose is to avoid or resolve norm conflicts between federal law and state law. ${ }^{27}$ Though federal law is hierarchically

21. See Dinah Shelton, International Law and 'Relative Normativity', in INTERNATIONAL LAW 145 (Malcolm D. Evans ed., 2003) (analyzing the three current topics of debate concerning relative normativity).

22. Of course, even within a centralized and hierarchical system, courts often employ techniques of harmonious interpretation so as to avoid conflict. See, e.g., INS v. St. Cyr, 533 U.S. 289, 299-300 (2001) and Crowell v. Benson, 285 U.S. 22, 62 (1932) (employing the interpretative canon of constitutional avoidance, that statutes should read so far as is possible in such a way as to be compatible with the Constitution).

23. See PAUWELYN, supra note 15 , at $94-96$.

24. See Alfred Verdross, Jus Dispositivum and Jus Cogens in International Law, 60 AM. J. INT'L L. 55, 58 (1966).

25. See VCLT, supra note 14, arts. 53, 64. See also PAUWELYN, supra note 15, at 278-82.

26. U.S. CONST., art. VI, cl. 2.

27. See, e.g., Symposium, Ordering State-Federal Relations Through Federal Preemption Doctrine, 102 Nw. U. L. REV. 503 (2008). 
superior to state law, it has this preemptive effect only if enacted pursuant to the limited grant of powers given to the federal government by the Constitution.

In international law, the only analogous situation is that of law-making within international organizations, which were granted certain powers by a treaty between their member states. Accordingly, if a body of an organization, for example the United Nations, has some sort of law-making capacity, that capacity is necessarily limited by its constituent instrument. Thus, a resolution passed by the UN Security Council in violation of the UN Charter would be ultra vires and therefore void - an issue which I will address later. ${ }^{28}$

In all other cases, the principal legislators of international law, nearly two hundred states, are sovereign equals. They are, moreover, equals who are exercising their powers through multiple, heterogeneous law-making processes, during which they rarely take into account the possibility of conflict with other norms or legal regimes. ${ }^{29}$ As a consequence, most of the methods for conflict resolution that are applied in domestic systems are less useful in international law. ${ }^{30}$ Moreover, the plural legislators of the diffuse international legal system are perfectly capable of making contradictory commitments, and to presume coherence in the intent of states in all circumstances would fly in the face of reality. ${ }^{31}$ Therefore, in international law it is conceptually entirely possible for norm conflicts to exist that are both unavoidable and unresolvable.

With this basic framework in mind, let us now turn to Article 103 of the Charter and the first cases of human rights norm conflict to be discussed this article.

28. See PAUWELYN, supra note 15 , at $96,285-90$.

29. On conflict clauses in treaties, see generally Christopher J. Borgen, Resolving Treaty Conflicts, 37 GEO. WASH. INT'L L. REV. 573, 584-87 (2005) (addressing drafting techniques for avoiding treaty conflicts); ILC Study, supra note 1, paras. 267-71 (analyzing conflict-clauses in treaties).

30. See Shelton, supra note 21 , at 147.

31. See ILC Study, supra note 1, para. 34 ("There is no single legislative will behind international law. Treaties and custom come about as a result of conflicting motives and objectives - they are "bargains" and "package-deals" and often result from spontaneous reactions to events in the environment."). 


\section{ARTICLE 103 OF THE CHARTER, HUMAN RIGHTS AND THE POWERS OF THE SECURITY COUNCIL}

A. Scope and Effects of Article 103

Article 103 of the Charter reads as follows:

In the event of a conflict between the obligations of the Members of the United Nations under the present Charter and their obligations under any other international agreement, their obligations under the present Charter shall prevail.

Article 103 is unique in international practice. It is not limited merely to prohibiting inter se agreements between member states, or the conclusion of conflicting treaties, as was the case, for example, with Article 20 of the League of Nations Covenant. ${ }^{32}$ Generally speaking, when states conclude treaties that conflict with a previous multilateral treaty to which they are a party, but which do not abrogate the latter, they incur responsibility for such an action. However, though this second treaty might be contrary to the provisions of an earlier one, and thus 'illegal', it is not thereby invalidated and still has legally binding force as the product of valid state consent. ${ }^{33}$ Therefore, the fact that an earlier treaty prohibited the conclusion of the latter treaty would not in itself constitute an excuse for a state for its failure to perform this new treaty - after all, it freely consented to it.

Article 103 is distinct in three respects that jointly make it the only truly meaningful prospective conflict clause. First, under its terms, a Charter obligation will prevail over any conflicting obligation. That does not mean that the conflicting norm is invalidated, as with conflicts involving norms of jus cogens. The conflicting norm remains valid and continues to exist, albeit in suspended animation - the state is merely prohibited from following it. ${ }^{34}$ Secondly, though other prospective conflict clauses can be extinguished simply by the fact that all of the contracting parties to the treaty conclude another treaty, "an agreement concluded by some or even all UN members, without amending Article 103, would not prevail over the UN Charter." ${ }^{35}$ Indeed, Article 30(1) of the Vienna Convention on the Law of Treaties explicitly subjects the application of the lex posterior rule to Article 103 of the Charter. Finally, Article 103 is not a

32. See id. para. 328 .

33. See PAUWELYN, supra note 15, at 277.

34. See ILC Study, supra note 1, paras. 333-34. See also Rain Liivoja, The Scope of the Supremacy Clause of the United Nations Charter, 57 INT'L \& COMP. L.Q. 583, 597 (2008) (arguing that "Charter-based obligations simply take precedence over other treaties, should conflicts arise.").

35. PAUWELYN, supra note 15 , at 339. 
simple rule of priority - it also precludes or removes any wrongfulness due to the breach of the conflicting norm. ${ }^{36}$ In other words, a state cannot be called to account for complying with its obligations under the Charter, even if in doing so it must violate some other rule - any rule, that is, except a rule of jus cogens. ${ }^{37}$

Let us illustrate this through an example. States A, B and C conclude a treaty of friendship, whereby they agree to freely trade with one another, and undertake not to conclude any other agreements that would violate this commitment. After some time, states A and B become disaffected with the treaty and conclude a new trade agreement leaving out state $\mathrm{C}$ in contravention of the earlier treaty. This new inter se agreement is thus "illegal" under the terms of the previous treaty. Even so, both treaties have equal binding force, and states $\mathrm{A}$ and $\mathrm{B}$ will incur responsibility for breaching either of them.

If, however, the UN Security Council, acting under Chapter VII of the Charter, determines that state $\mathrm{C}$ is engaged in a threat to or a breach of international peace and security, and orders states A and B to implement trade sanctions against state $\mathrm{C}$, they would be obliged to do so notwithstanding their earlier trade agreement. They would incur no responsibility for failing to comply with that agreement, as Article 103 of the Charter would preclude any wrongfulness of their actions under the treaty.

Even though Article 103 of the Charter is, strictly speaking, not a rule of hierarchy, such as jus cogens, since it does not result in the invalidation of a conflicting lower norm, it still largely resembles such a rule. Many authors consequently see in Article 103 a confirmation of the constitutional character of the Charter as the founding instrument of the post-Second World War international legal order. ${ }^{38}$ This is the first of several constitutionalist agendas that we will encounter.

It should also be noted that Article 103 does not merely say that the Charter itself will prevail over conflicting obligations, but that member

36. There is no provision in the ILC Articles on State Responsibility that explicitly gives such preclusive effect to Article 103. Draft Articles on Responsibility of States for Internationally Wrongful Acts, G.A. Res. 56/83, Annex, pt.4, art. 59 cmt. 1, U.N. Doc A/RES/56/83 (Dec. 12, 2001), available at http://untreaty.un.org/ilc/texts/instruments/english/draft\%20articles/9_6_2001.pdf [hereinafter ILC Articles on State Responsibility]. However, Article 59 of the ILC Articles provides that they are without prejudice to the UN Charter. Id. at art. 59. The ILC commentary to this article makes it clear that this provision was inserted precisely to cover Article 103. Id. at Annex, pt.4, art. $59 \mathrm{cmt} .1$.

37. See ILC Study, supra note 1, paras. 333-40.

38. See Rudolf Bernhardt, Article 103, in 2 ThE ChARTER of the United NATIONS - A COMmentary 1292 (Bruno Simma ed., 2002); Bardo Fassbender, The United Nations Charter as Constitution of the International Community, 36 COLUM. J. TRANSNAT'L L. 529 (1998). 
states' obligations under the Charter will so prevail. This formulation is broader, as it encompasses state obligations arising from binding decisions of UN organs, primarily the Security Council, pursuant to Article 25 of the Charter, as in the example given above. ${ }^{39}$ That the primacy effect of Article 103 also extends to binding Security Council resolutions has been confirmed by both doctrine and practice, ${ }^{40}$ as well as by the ICJ in the Lockerbie case. $^{41}$

Two further questions become apparent upon reading Article 103. First, by its own terms it applies only to a conflict with a Charter obligation. However, in practice the Security Council often authorizes states to do something in a legally binding resolution, for example to use force, but does not oblige them to do so. Second, Article 103 states only that Charter obligations prevail over conflicting obligations under any other 'international agreement', such as a treaty. Hence the question arises whether Charter obligations also prevail over states' conflicting customary or other non-treaty legal obligations.

Doctrine has overwhelmingly answered both of these questions in the affirmative, in both cases on policy grounds and without much textual support in the Charter. ${ }^{42}$ Because authorizations by the Council to member states have effectively taken over the role of armed forces under UN command, as was originally envisaged in the Charter, and thus have a central place in the system of collective security, ${ }^{43}$ Article 103 has generally been interpreted to extend to Council authorizations as well as to its commands. ${ }^{44}$ Moreover, since obligations under a customary rule frequently run in parallel with treaty obligations that have the same

39. See Liivoja, supra note 34 , at 585-89.

40. See ILC Study, supra note 1, para. 331 .

41. Questions of Interpretation and Application of the 1971 Montreal Convention arising from the Aerial Incident at Lockerbie (Libya v. U.K.), para. 37 (Req. for Provisional Measures) (Order of Apr. 14, 1992), available at http://www.icj-cij.org/docket/files/88/7085.pdf.

42. See Dan Sarooshi, The United Nations and the Development of Collective SeCurity: The Delegation By the UN SECURITy COUNCIL OF ITS CHAPTER VII POWERS 150-51 (1999); Jochen Frowein \& Nico Krisch, Article 39, in 1 THE CHARTER OF THE UNITED NATIONS - A COMmEnTARY 717, at MN 33 (Bruno Simma ed., 2002); Robert Kolb, Does Article 103 of the Charter of the United Nations Apply only to Decisions or also to Authorizations Adopted by the Security Council?, 64 ZEITSCHRIFT FÜR AUSLÄNDISCHES ÖFFENTLICHES RECHT UND VÖLKERRECHT [ZAÖRV] 21 (2004), available at http://www.zaoerv.de/64_2004/64_2004_1_a_21_36.pdf; Wood, First Lecture, supra note 4, paras. 51-57.

43. See generally ERIKA DE WET, THE CHAPTER VII POWERS OF THE UNITED NATIONS SECURITY COUnCIL (2004); Niels Blokker, Is the Authorization Authorized? Powers and Practice of the UN Security Council to Authorize the Use of Force by "Coalitions of the Able and Willing”, 11 EUR. J. INT'L L. 541 (2000).

44. See, e.g., Alan Boyle \& Christine Chinkin, THE MAKING OF InTERnAtional LAW 232-33 (2007). 
substantive content, it would run contrary to the object and purpose of Article 103 if it could only preclude a state's responsibility for failing to abide by the treaty, and not by the identical customary rule. ${ }^{45}$

With these preliminary remarks on Article 103 out of the way, we now turn to examining the actual cases in which it played a key role. In both $\mathrm{Al}$ Jedda before the House of Lords ${ }^{46}$ and Behrami and Saramati before the European Court of Human Rights ${ }^{47}$ a grant of authority from the Council to certain member states was interpreted by these states as inter alia allowing them to engage in preventative detention without judicial review, in Iraq and Kosovo respectively. We will then move on to cases before EU courts that concern targeted sanctions by the Council against individuals suspected of financing terrorism.

\section{B. Al-Jedda and Behrami}

In June 2004 the Security Council adopted Resolution 1546 (2004), which was to provide the legal framework for the continued presence of the coalition or multi-national forces (MNF) in Iraq after the occupation of the country came to an end. In particular, the resolution independently granted these forces some of the rights that they enjoyed as occupiers under the law of armed conflict. The specific right that concerns us here is the occupier's power to preventatively detain persons for security reasons, stipulated in Article $42(1)$ of the Fourth Geneva Convention:" "The internment or placing in assigned residence of protected persons may be ordered only if the security of the Detaining Power makes it absolutely necessary," as well as in Article 78 thereof: "If the Occupying Power considers it necessary, for imperative reasons of security, to take safety measures concerning protected persons, it may, at the most, subject them to assigned residence or to internment." 49

45. For dissenting views on Article 103's applicability to customary norms, see Derek Bowett, The Impact of Security Council Decisions on Dispute Settlement Procedures, 5 EuR. J. INT'L L. 89, 92 (1994); Liivoja, supra note 34, at 602-12.

46. R (In re Al-Jedda) v. Sec'y of State for Def., [2007] UKHL 58, [2008] 1 A.C. 332 (appeal taken from Eng.), available at http://www.bailii.org/uk/cases/UKHL/2007/58.html.

47. Behrami and Behrami v. France, Saramati v. France, Germany, and Norway, App. Nos. 71412/01, 78166/01, Eur. Ct. H.R. (2 May 2007), available through the HUDOC database at http://www.echr.coe.int/echr/en/hudoc.

48. Geneva Convention (IV) Relative to the Protection of Civilian Persons in Time of War art. 42, Aug. 12, 1949, 6 U.S.T. 3516, 75 U.N.T.S. 287.

49. Id. art. 78. Article 43(1) further provides that "Any protected person who has been interned or placed in assigned residence shall be entitled to have such action reconsidered as soon as possible by an appropriate court or administrative board designated by the Detaining Power for that purpose. If the internment or placing in assigned residence is maintained, the court or administrative board shall 
Acting under Chapter VII of the Charter, the Council decided "that the multinational force shall have the authority to take all necessary measures to contribute to the maintenance of security and stability in Iraq in accordance with the letters annexed to this resolution expressing, inter alia, the Iraqi request for the continued presence of the multinational force and setting out its tasks, including by preventing and deterring terrorism."50 The referenced letters were sent to the Council by the U.S. Secretary of State Colin Powell, and the then interim Prime Minister of Iraq Ayad Allawi. Both letters emphasized the ongoing security threats in Iraq and the need to put them to an end. In particular, Secretary Powell's letter outlined the duties of the MNF forces, stating that these "will include combat operations against members of [insurgent] groups, internment where this is necessary for imperative reasons of security, and the continued search for and securing of weapons that threaten Iraq's security."51

Under this authority, in October 2004 British troops of the MNF detained Mr. Al-Jedda as a security threat. ${ }^{52}$ The detention was authorized and periodically reviewed by senior officers of the British army. Mr. AlJedda challenged his detention before English courts, relying on Article 5(1) of the European Convention on Human Rights (the ECHR rights being transformed into English law by virtue of the Human Rights Act 1998 (HRA)), which enshrines the right to liberty of person and does not allow for internment on security grounds. ${ }^{53}$ The government opposed his

periodically, and at least twice yearly, give consideration to his or her case, with a view to the favourable amendment of the initial decision, if circumstances permit." Id. art. 43(1).

50. S.C. Res. 1546, ๆ 10, U.N. Doc. S/RES/1546 (June 8, 2004) (emphasis added).

51. Id. at Annex (emphasis added).

52. R (In re Al-Jedda) v. Sec'y of State for Def., [2007] UKHL 58, paras. 1-2, [2008] 1 A.C. 332

(H.L.) (appeal taken from Eng.) (U.K.), available at http://www.bailii.org/uk/cases/UKHL/ 2007/58.html.

53. Article 5(1) provides an exhaustive list of grounds on which a person may be deprived of his liberty:

Everyone has the right to liberty and security of person. No one shall be deprived of his liberty save in the following cases and in accordance with a procedure prescribed by law:

(a) the lawful detention of a person after conviction by a competent court;

(b) the lawful arrest or detention of a person for non-compliance with the lawful order of a court or in order to secure the fulfilment of any obligation prescribed by law;

(c) the lawful arrest or detention of a person effected for the purpose of bringing him before the competent legal authority on reasonable suspicion of having committed an offence or when it is reasonably considered necessary to prevent his committing an offence or fleeing

after having done so;

(d) the detention of a minor by lawful order for the purpose of educational supervision or his lawful detention for the purpose of bringing him before the competent legal authority;

(e) the lawful detention of persons for the prevention of the spreading of infectious diseases, of persons of unsound mind, alcoholics or drug addicts or vagrants; 
challenge on two main grounds. First, it argued that in this particular situation the ECHR and the HRA did not apply extraterritorially. Second, even if they did, internment was authorized by a binding resolution of the Security Council, which prevailed over Article 5(1) under the terms of Article 103 of the Charter. The government desisted from its first argument after the House of Lords decided the Al-Skeini case, in which it established that the HRA and ECHR do apply to persons detained by British forces in Iraq. ${ }^{54}$ However, both the High Court and the Court of Appeal, and ultimately the House of Lords found against Mr. Al-Jedda on the basis of Article 103. Let us now examine their Lordships' ruling in detail.

Lord Bingham, who delivered the lead opinion, first dealt with $\mathrm{Mr}$. Al-Jedda's argument that Article 103 was inapplicable, since Resolution 1546 merely authorized the UK to detain persons considered to be security threats, but did not oblige it to do so. He did not find that argument persuasive. He considered that both state practice and academic opinion clearly favored the applicability of Article 103 to Council authorizations, as the importance of maintaining peace and security in the world could scarcely be exaggerated, and since authorizations have effectively replaced the system of collective security that was envisaged by the drafters. ${ }^{55}$ Lord Bingham then rejected the argument that Article 103 should not apply to the ECHR, due to the latter's special character as a human rights treaty, as Article 103 applies to all international agreements. ${ }^{56}$

For Lord Bingham, the conflict between two fundamental interests that of protecting international peace and security on the one hand, and that of protecting human rights on the other, was truly acute, since it was difficult to see how any exercise of the power to detain preventatively, however necessary for imperative reasons of security, and however strong

(f) the lawful arrest or detention of a person to prevent his effecting an unauthorised entry into the country or of a person against whom action is being taken with a view to deportation or extradition.

Convention for the Protection of Human Rights and Fundamental Freedoms, art. 5(1), Nov. 4, 1950, 213 U.N.T.S. 222. The drafters of the ECHR deliberately chose to include an exhaustive list of grounds for detention in Article 5(1), instead of a general standard, such as, for example, the one in Article 9(1) of the ICCPR which merely prohibits arbitrary detention, but does not specify what types of detention qualify as arbitrary. See Al-Jedda, [2007] UKHL 58, para. 122 (Baroness Hale, concurring).

54. $R$ (Al-Skeini and others) v. Sec'y of State for Def., [2007] UKHL 26, [2007] 3 WLR 33 (appeal taken from Eng.). For commentary on the decision, see Tobias Thienel, The ECHR in Iraq: The Judgment of the House of Lords in R (Al-Skeini) v. Secretary of State for Defence, 6 J. INT'L CRIM. JUST. 115 (2008). On the extraterritorial application of human rights treaties, see generally Marko Milanović, From Compromise to Principle: Clarifying the Concept of State Jurisdiction in Human Rights Treaties, 8 Hum. RTS. L. ReV. 411 (2008); EXTRATERritorial APPLiCATION OF HuMAN Rights Treaties (Fons Coomans \& Menno T. Kamminga eds., 2004).

55. Al-Jedda, [2007] UKHL 58 paras. 33-34. See also id. para. 115 (Lord Rodger, concurring).

56. Id. para. 35 (per Lord Bingham). 
the safeguards afforded to the detainee, could do otherwise than breach the detainee's rights under Article 5(1). ${ }^{57}$

Lord Bingham thus concluded that there was a genuine norm conflict between a Charter obligation of the UK and Article 5(1) of the ECHR, and that the Charter obligation must prevail:

Thus there is a clash between on the one hand a power or duty to detain exercisable on the express authority of the Security Council and, on the other, a fundamental human right which the UK has undertaken to secure to those (like the appellant) within its jurisdiction. How are these to be reconciled? There is in my opinion only one way in which they can be reconciled: by ruling that the UK may lawfully, where it is necessary for imperative reasons of security, exercise the power to detain authorised by UNSCR 1546 and successive resolutions, but must ensure that the detainee's rights under article 5 are not infringed to any greater extent than is inherent in such detention. ${ }^{58}$

Though Lord Bingham affirmed the judgment of the Court of Appeal on the issue of Article 103, his opinion introduces an element of subtlety lacking in that of the court below, evident in the somewhat cryptic italicized phrase in the quotation above. Yes, Mr. Al-Jedda cannot complain solely because his detention was on preventative grounds, but his rights must not be infringed to any greater extent than is inherent in such preventative detention. The exhaustive list of grounds of detention from Article 5(1) of the ECHR might have temporarily disappeared by virtue of Article 103 of the Charter, yet not only does a kernel of Article 5(1) remain in that the detention must not be unreasonable, but security detainees have other rights under Article 5 - to be informed of the reasons behind their arrest (Article 5(2)), to be able to challenge the lawfulness of their detention before a court (Article 5(4)) and to be compensated for any unlawful detention (Article 5(5)). Judicial review of detention in particular would be a major departure from the internment regime under the law of occupation, which allows for review by mere administrative boards. ${ }^{59}$

This is of course all between the lines of Lord Bingham's opinion - he says none of this explicitly, as the issue raised in the case was solely under Article 5(1) of the ECHR, not Article 5(4). ${ }^{60}$ But other Law Lords also gave similar hints. Thus, Baroness Hale remarked that

57. See id. para. 37.

58. Id. para. 39 (emphasis added). See also id. para. 118 (Lord Roger, concurring); id. paras. 12526 (Baroness Hale, concurring); id. para. 131 (Lord Carswell, concurring).

59. Geneva Convention (IV) Relative to the Protection of Civilian Persons in Time of War, supra note 48 , art. 43 .

60. See also Al-Jedda, [2007] UKHL 58 para. 46 (Lord Rodger, concurring). 
The right is qualified but not displaced. This is an important distinction, insufficiently explored in the all or nothing arguments with which we were presented. We can go no further than the UN has implicitly required us to go in restoring peace and security to a troubled land. The right is qualified only to the extent required or authorised by the resolution. What remains of it thereafter must be observed. This may have both substantive and procedural consequences. ${ }^{61}$

Lord Carswell added that

[W]here a state can lawfully intern people, it is important that it adopt certain safeguards: the compilation of intelligence about such persons which is as accurate and reliable as possible, the regular review of the continuing need to detain each person and a system whereby that need and the underlying evidence can be checked and challenged by representatives on behalf of the detained persons, so far as is practicable and consistent with the needs of national security and the safety of other persons. $^{62}$

I would emphasise, however, that that power [to detain] has to be exercised in such a way as to minimise the infringements of the detainee's rights under article 5(1) of the Convention, in particular by adopting and operating to the fullest practicable extent safeguards of the nature of those to which I referred [to] above. ${ }^{63}$

In Al-Jedda we can clearly see the presumption against norm conflict at work. Even though Resolution 1546 did prevail over Article 5(1) of the ECHR by virtue of Article 103 of the Charter, it did so only to the extent inherent in preventative detention. Even in cases of genuine norm conflict, especially those involving human rights, the scope of the conflict will be minimized through interpretation. Other methods of conflict resolution and avoidance could have been applied by the House in Al-Jedda, but they were either not relied on by the parties or were not to their Lordships' liking. We will come to some of these below, but first we must turn to the Behrami and Saramati case before the European Court of Human Rights. ${ }^{64}$ This case was in effect Al-Jedda's sibling, not only because they raised similar issues, but also as the litigation in the two cases ran in parallel: the lower courts in Al-Jedda ruled first, then the European Court decided Behrami, and finally the House of Lords delivered its own judgment in Al-Jedda.

61. Id. para. 126 (Baroness Hale, concurring).

62. Id. para. 130 (Lord Carswell, concurring).

63. Id. para. 136.

64. See also the later case of Berić v. Bosnia and Herzegovina, App. Nos. 36357/04 (etc.), Eur. Ct. H.R. (16 October 2007), available through the HUDOC database at http://www.echr.coe.int/ echr/en/hudoc (relying on Behrami, a Chamber of the Court ruled that the acts of the international High Representative in Bosnia were attributable to the UN). 
Behrami and Saramati were two joined cases filed against several states participating in KFOR, the NATO-led peacekeeping mission in Kosovo. ${ }^{65}$ In Behrami, the applicants were the family of a boy who died while playing in an unmarked field saturated with undetonated cluster bombs. They alleged that the respondent state had the positive obligation to secure the right to life of the victim, which it failed to fulfill. The Saramati case is of more interest to our present discussion, as its facts closely follow Al-Jedda. The applicant was preventatively detained by the KFOR commander as a security threat to the international presence in Kosovo, without recourse to judicial review of his detention. KFOR based its power to detain on Security Council Resolution 1244 (1999), which authorized "Member States and relevant international organizations to establish the international security presence in Kosovo ... . with all necessary means to fulfill its responsibilities." ${ }^{66} \mathrm{As}$ in $\mathrm{Al}$-Jedda, the applicant based his claim on Article 5 of the ECHR.

The European Court's approach to the case was completely different from that of the English courts in Al-Jedda. The Court said nary a word about norm conflict, and mentioned Article 103 of the Charter only in passing, ${ }^{67}$ even though it was extensively relied on by the respondent states. ${ }^{68}$ It disposed of the case on grounds of attribution, ruling that the impugned acts could not be attributed to the respondent states, but solely to the United Nations. It first reasoned that the Security Council was by Resolution 1244 "delegating to willing organisations and members states ... the power to establish an international security presence as well as its operational command. Troops in that force would operate therefore on the basis of UN delegated, and not direct, command." 69 That notion of delegation would prove to be crucial in the Court's attribution analysis:

While Chapter VII constituted the foundation for the above-described delegation of UNSC security powers, that delegation must be sufficiently limited so as to remain compatible with the degree of centralisation of UNSC collective security constitutionally necessary under the Charter and, more specifically, for the acts of the delegate entity to be attributable to the $\mathrm{UN}^{70}$

65. For a discussion of these cases, see Pierre Bodeau-Livinec et al., 102 AM. J. INT'L L. 323 (2008).

66. S.C. Res. 1244, para. 7, U.N. Doc. S/RES/1244 (June 10, 1999).

67. See Behrami and Behrami v. France, Saramati v. France, Germany, and Norway, App. Nos. 71412/01, 78166/01, Eur. Ct. H.R., paras. 26, 147 (2 May 2007), available through the HUDOC database at http://www.echr.coe.int/echr/en/hudoc.

68. See id. paras. 97, 102, 106, 113.

69. Id. para. 129.

70. Id. para. 132 . 
Hence, in the Court's view, attribution depended upon "whether the UNSC retained ultimate authority and control so that operational command only was delegated."71 After examining the conditions it thought necessary for a lawful delegation of the Council's power the Court found this test to be met, ${ }^{72}$ and concluded that KFOR "was exercising lawfully delegated Chapter VII powers of the UNSC so that the impugned action was, in principle, "attributable" to the UN."73 Since the violations in question were not attributable to the respondent states, but to the UN, which is not itself a party to the ECHR, the Court found that the applications were incompatible with the Convention due to lack of jurisdiction ratione personae. ${ }^{74}$

The attribution issue in Behrami was wrongly decided. A detailed account of why this is so is for elsewhere. ${ }^{75}$ For our present purposes, suffice it to say that the Court conflated two entirely separate questions the delegation of powers by the Security Council and that of state responsibility. The Council may or may not have delegated some of its powers to KFOR, but it is its effective control over KFOR or, indeed, the lack thereof, that is dispositive for attribution. ${ }^{76}$ The Court, moreover, found some support for its attribution analysis solely in the work of a single author, $^{77}$ and it failed to discuss or even acknowledge the otherwise unanimous contrary authorities, ranging from the legal opinions of the UN itself, to those of the ILC and of numerous scholars, to the effect that the UN cannot be responsible for the acts of troops over which it does not have operational control. ${ }^{78}$ Finally, the Court's decision produces unacceptable results as a matter of policy, as it allows states to retain control over their

71. Id. para. 133 .

72. Id. paras. $134-40$.

73. Id. para. 141.

74. Id. paras. $144-52$

75. See Marko Milanović \& Tatjana Papić, As Bad As It Gets: The European Court of Human Rights' Behrami and Saramati Decision and General International Law, 58 INT'L \& COMP. L.Q. 267 (2009).

76. See Int'1 Law Comm'n Report of the International Law Commission on the Work of its FiftySixth Session, at 99, U.N. GAOR, 59th Sess., Supp. No. 10, U.N. Doc. A/59/10, Draft Article 5 (2004).

77. See Milanović \& Papić, supra note 75 (relying on Sarooshi, supra note 42, at 163-66).

78. See, e.g., European Commission for Democracy through Law (Venice Commission), Opinion on Human Rights in Kosovo: Possible establishment of review mechanisms, 60th Sess., Doc. No. 280, at 18 (2004), available at http://www.venice.coe.int/docs/2004/CDL-AD(2004)033-e.pdf; Rüdiger Wolfrum, International Administration in Post-Conflict Situations by the United Nations and Other International Actors, 9 MAX PLANCK Y.B.U.N. L. 649, 690 (2005); Andreas Paulus, Article 29, in 1 The Charter of the United NATIONS - A COMMENTARy 539, at MN 9 (Bruno Simma ed., 2002); Jochen Frowein \& Nico Krisch, Article 42, in 1 THE ChARTER OF THE United NATIONS - A COMmentary 749, at MN 759 (Bruno Simma ed., 2002); C.F. AMERASINGHe, Principles OF THE INSTITUTIONAL LAW OF INTERNATIONAL ORGANIZATIONS 403 (2005); John Cerone, Minding the Gap: Outlining KFOR Accountability in Post-Conflict Kosovo, 12 EUR. J. INT’L L. 469, 486 (2001). 
armed forces in peacekeeping operations instead of putting them at the disposal of the UN, and at the same time allows them to blame the UN for any of their actions. ${ }^{79}$

There can thus be little doubt that the Court's attribution reasoning in Behrami is untenable. ${ }^{80}$ Yet, how can we explain the very obviousness of the flaws in the Court's decision? In my view there is at least one possible explanation - what the Court said in its decision is conditioned above all by the things that it did not want to say. The issue that it wanted to avoid the most was precisely that of norm conflict and the preemptive effect of Article 103 of the Charter. It did not, it would not, say that Resolution 1244 prevailed over Article 5 of the ECHR, as the English courts did in $\mathrm{Al}$ Jedda. For the European Court, the ECHR is the "constitutional instrument of European public order," 81 of which the Court itself is the ultimate guardian. Accepting in Behrami that fifteen states sitting in the Security Council could whisk away this "constitutional instrument" on the basis of Article 103 would have created a precedent capable of abuse in a not-sodistant future. On the other hand, the Court also did not want to openly defy the Council or interfere with the Chapter VII system and peacekeeping operations such as Kosovo - sympathize with the applicants it might, but rule in their favor it would not. And so the Court came up with its strained attribution to the UN rationale, which solved its immediate problems. It not only avoided a norm conflict, but also what the Court saw as a conflict of constitutional importance.

\section{Kadi and $O M P I$}

I now turn to the Court of First Instance of the European Communities (CFI), which decided several cases on sanctions imposed by the Security

79. The issue of attribution was also raised in Al-Jedda before the House of Lords, after Behrami was decided. The House refused to follow Behrami, inter alia because it would produce simply absurd consequences in the Iraq context, as it would for example be the UN, instead of the U.S., who would bear responsibility for the Abu Ghraib torture scandal. The House managed to avoid relying on Behrami not by holding that it was wrongly decided, but by (not entirely persuasively) distinguishing it on the facts. See also Milanović \& Papić, supra note 75.

80. See also Bodeau-Livinec et al., supra note 65, at 325-31; Aurel Sari, Jurisdiction and International Responsibility in Peace Support Operations: The Behrami and Saramati Cases, 8 Hum. RTS. L. REV. 51, 162-65 (2008); Bernhard Knoll, Rights Without Remedies: The European Court's Failure to Close the Human Rights Gap in Kosovo, 68 ZEITSCHRIFT FÜR AUSLÄNDISCHES ÖFFENTLICHES RECHT UND VÖLKERRECHT [ZAÖRV]; Kjetil Mujezinovic Larsen, Attribution of Conduct in Peace Operations: The 'Ultimate Authority and Control' Test, 19 EUR. J. INT'L L. 509, 52025 (2008).

81. Behrami and Behrami v. France, Saramati v. France, Germany, and Norway, App. Nos. 71412/01, 78166/01, Eur. Ct. H.R. (2 May 2007), available through the HUDOC database at http:// www.echr.coe.int/echr/en/hudoc. 
Council against suspected terrorists and their supporters. The cases are highly complex, and I will only deal with issues of norm conflict that appear therein. The first to be examined are Yusuf and Kadi. ${ }^{82}$ As the two cases are nearly identical, Kadi will be the one referred to throughout the article. In the background of the case are the sanctions originally established by the Security Council in its Resolution 1267 (1999) against the Taliban regime in Afghanistan. The sanctions regime was expanded by subsequent resolutions to the Al-Qaeda network and persons associated with it. ${ }^{83}$ The Council set up a Sanctions Committee as its subsidiary body to monitor the implementation of sanctions, which maintained lists of suspected terrorists. UN member states were obliged to enforce sanctions against these listed individuals.

Having this sanctions regime in view, the member states of the European Union $(\mathrm{EU})^{84}$ decided that instead of implementing this regime individually in their respective domestic legal systems, they should do so through EU mechanisms. The EU Council thus adopted several common positions, as well as Regulation No. 881/2002, implementing the sanctions regime. Annexed to the Regulation was the list of persons whose funds were to be frozen, on the basis of the lists made by the Sanctions Committee of the Security Council. As Community law, the Regulation had direct effect in the legal orders of the member states and took precedence over any contrary domestic legislation.

The assets of the applicant in Kadi were frozen in this manner. He complained to the CFI, seeking to annul the implementing Regulation on the grounds that it violated his fundamental human rights as protected by primary EU law (that, under long-standing jurisprudence, protects as general principles a corpus of fundamental rights, including the rights enshrined in the ECHR), including the right to a fair hearing, the right to property and the right to judicial review. ${ }^{85}$ One of his key arguments was that

[T]he Security Council resolutions relied on by the [EU] Council and the Commission do not confer on those institutions the power to abrogate those fundamental rights without justifying that stance before the Court by producing the necessary evidence. As a legal order independent of the United Nations, governed by its own rules of law, the European Union

82. Case T-306/01, Yusuf and Al Barakaat Int'1 Found. v. Council and Comm'n, 2005 E.C.R. II3533; Case T-315/01, Kadi v. Council and Comm'n, 2005 E.C.R. II-3649.

83. See generally Chia Lehnardt, European Court Rules on UN and EU Terrorist Suspect Blacklists, AM. SOC'Y OF INT'L L INSIGHTS, Jan. 31, 2007, http://www.asil.org/insights070131.cfm.

84. Purely as a matter of convenience, the terms European Union and European Community (EC) will be used interchangeably throughout this paper, as will EU law, EC law and Community law.

85. Kadi, 2005 E.C.R. II-3649. para. 59. 
must justify its actions by reference to its own powers and duties vis-àvis individuals within that order. ${ }^{86}$

The import of this argument cannot be overemphasized, as it challenges the most fundamental operating assumption of Article 103 of the Charter. Like any rule of hierarchy (or something closely resembling one), it can only prevail over a norm which is a part of the same legal order. As the United States Constitution is the supreme law only in the United States legal system, but not in the legal orders of France or China, so is Article 103 of the Charter superior law only in the international legal system. According to Kadi's argument, however, he was entitled to human rights protections under EU law, and that legal order "was independent of the United Nations." The Security Council resolution could not prevail over these rights, as it could not penetrate this independent legal order. This, as we shall see, was one of the main themes of the Advocate-General's opinion in Kadi, as wells as the decision on appeal of the European Court of Justice (ECJ), to which we will turn shortly.

On the other hand, the EU Council and Commission submitted

[F]irst, that the Community, like the Member States of the United Nations, is bound by international law to give effect, within its spheres of competence, to resolutions of the Security Council, especially those adopted under Chapter VII of the Charter of the United Nations; second, that the powers of the Community institutions in this area are limited and that they have no autonomous discretion in any form; third, that they cannot therefore alter the content of those resolutions or set up mechanisms capable of giving rise to any alteration in their content and, fourth, that any other international agreement or domestic rule of law liable to hinder such implementation must be disregarded.

[A]s members of the United Nations, the Member States of the Community have agreed to carry out without reservation the decisions taken in their name by the Security Council, in the higher interest of the maintenance of international peace and security (see Articles 24(1) and 25 of the Charter of the United Nations). The obligations imposed on a Member of the United Nations under Chapter VII of the Charter of the United Nations prevail over every other international obligation to which the member might be subject. In that way Article 103 of the Charter makes it possible to disregard any other provision of international law, whether customary or laid down by convention, in order to apply the resolutions of the Security Council, thus creating an 'effect of legality'. 87

\footnotetext{
86. Id. para. 140 .

87. Id. paras. 153,156 .
} 
Hence, the parties put before the CFI a much more fundamental question than the resolution of a single norm conflict - that of the relationship between general international law and EU law. ${ }^{88}$ Only if the Court found that the two legal orders were one, even though to a great extent autonomous, could it entertain the Article 103 argument. It went on to do just that. First, it held that

From the standpoint of international law, the obligations of the Member States of the United Nations under the Charter of the United Nations clearly prevail over every other obligation of domestic law or of international treaty law including, for those of them that are members of the Council of Europe, their obligations under the ECHR and, for those that are also members of the Community, their obligations under the EC Treaty.

...

With more particular regard to the relations between the obligations of the Member States of the Community by virtue of the Charter of the United Nations and their obligations under Community law, it may be added that, in accordance with the first paragraph of Article 307 EC, 'The rights and obligations arising from agreements concluded before 1 January 1958 or, for acceding States, before the date of their accession, between one or more Member States on the one hand, and one or more third countries on the other, shall not be affected by the provisions of this Treaty. ${ }^{89}$

\section{Furthermore,}

Article 224 of the Treaty establishing the European Economic Community (now Article 297 EC) was specifically introduced into the Treaty in order to observe the rule of primacy defined above. Under that provision, "Member States shall consult each other with a view to taking together the steps needed to prevent the functioning of the common market being affected by measures which a Member State may be called upon to take ... in order to carry out obligations it has accepted for the purpose of maintaining peace and international security., 90

The Court thus held that

$[P]$ ursuant both to the rules of general international law and to the specific provisions of the Treaty, Member States may, and indeed must, leave unapplied any provision of Community law, whether a provision of primary law or a general principle of that law, that raises any impediment to the proper performance of their obligations under the Charter of the United Nations. ${ }^{91}$

\footnotetext{
88. Id. para. 178 .

89. Id. paras. $181,185$.

90. Id. para. 188 .

91. Id. para. 190.
} 


\section{Moreover,}

unlike its Member States, the Community as such is not directly bound by the Charter of the United Nations and that it is not therefore required, as an obligation of general public international law, to accept and carry out the decisions of the Security Council in accordance with Article 25 of that Charter. The reason is that the Community is not a member of the United Nations, or an addressee of the resolutions of the Security Council, or the successor to the rights and obligations of the Member States for the purposes of public international law. Nevertheless, the Community must be considered to be bound by the obligations under the Charter of the United Nations in the same way as its Member States, by virtue of the Treaty establishing it. In that regard, it is not in dispute that at the time when they concluded the Treaty establishing the European Economic Community the Member States were bound by their obligations under the Charter of the United Nations. By concluding a treaty between them they could not transfer to the Community more powers than they possessed or withdraw from their obligations to third countries under that Charter. ${ }^{92}$

The Court thus rejected the applicant's argument that "the Community legal order is a legal order independent of the United Nations, governed by its own rules of law." 93

The Court then proceeded to examine the lawfulness of the contested Regulation. It found that the Regulation was merely implementing Security Council resolutions, and that neither the member states nor the EU institutions had any autonomous discretion in that regard. In particular, they could neither directly alter the content of the resolutions at issue nor set up any mechanism capable of giving rise to such alteration. ${ }^{94}$ If the Court were to review and annul the Regulation as violative of human rights, this would necessarily mean that resolutions that the Regulation was implementing were so violative. The Court would thus be exercising indirect review of a Security Council decision, a competence that both member states and EU institutions denied it had. ${ }^{95}$

The Court agreed that it lacked such competence, with the proviso that it could indirectly review "the lawfulness of the resolutions of the Security Council in question with regard to jus cogens, understood as a body of higher rules of public international law binding on all subjects of international law, including the bodies of the United Nations, and from which no derogation is possible." 96 If the Council's resolutions failed to

\footnotetext{
92. Id. paras. 192-95 (breaks and citations omitted).

93. Id. para. 208.

94. Id. paras. 213-14.

95. Id. paras. 216-17.

96. Id. para. 226 .
} 
observe norms of jus cogens, however improbable that may be, "they would bind neither the Member States of the United Nations nor, in consequence, the Community.",97

The Court then proceeded to conduct this limited form of review, which unsurprisingly ended up being deferential to the Security Council. The Court - with very little support - gave a very broad reading to jus cogens and considered that human rights such as the right to property or the right of access to a court fall within that category. Nonetheless, the limitations on the applicant's rights were justified, as they were inherent in the rights themselves as guaranteed by jus cogens. If anything, the judgment demonstrates the limited utility of jus cogens as a mechanism for conflict resolution, even in instances in which a court is prepared to broadly construe this body of norms. ${ }^{98}$

The challenge to the listing procedure failed in Kadi, but met with more success in Organisation des Modjahedines du peuple d'Iran $v$. Council (OMPI). ${ }^{99}$ In this case, at issue was not the listing process established under Resolution 1267, in which the Sanctions Committee drew up the lists of persons whose assets were to be frozen, but the process under Resolution 1373 (2001), which obliges member states to freeze assets and take various other measures in combating terrorism. This resolution, however, leaves discretion to the member states on how to designate persons for these sanctions and what kind of procedures to follow. The EU institutions passed Regulation No. 2580/2001 to implement Resolution 1373, and gave the EU Council the authority to maintain the lists of persons to whom the prescribed sanctions will be applied.

The difference between the two listing procedures proved to be crucial for the CFI:

It is, moreover, appropriate to mention the aspects which distinguish the present case from the cases which gave rise to the judgments in Yusuf and Kadi ... where it was held that the Community institutions were not required to hear the parties concerned in the context of the adoption and implementation of a similar measure freezing the funds of persons and entities linked to Osama bin Laden, Al-Qaeda and the Taleban.

That solution was justified in those cases by the fact that the Community institutions had merely transposed into the Community legal order, as they were required to do, resolutions of the Security Council and decisions of its Sanctions Committee that imposed the freezing of the funds of the parties concerned, designated by name, without in any way

97. Id. para. 230 .

98. See supra note 10 and accompanying text.

99. Case T-228/02, Org. des Modjahedines du people d'Iran v. Council of the European Union, 2006 E.C.R. II-4665 [hereinafter OMPI]. 
authorising those institutions, at the time of actual implementation, to provide for any Community mechanism whatsoever for the examination or re-examination of individual situations. ${ }^{100}$

In this case, by contrast, it was upon the Community to identify specifically the persons to whom the sanctions will apply, in accordance with the rules of its own legal order. ${ }^{101}$ The Court concluded that

[T] he Council maintained at the hearing that, in the implementation of Security Council Resolution 1373 (2001), the measures that it adopted under circumscribed powers, which thereby benefit from the principle of primacy as contemplated in Articles 25 and 103 of the United Nations Charter, are essentially those provided for by the relevant provisions of Regulation No. 2580/2001, which determine the content of the restrictive measures to be adopted in relation to the persons referred to in Paragraph 1(c) of that resolution. However, unlike the acts at issue in the cases which gave rise to the judgments in Yusuf and Kadi... the acts which specifically apply those restrictive measures to a given person or entity, such as the contested decision, do not come within the exercise of circumscribed powers and accordingly do not benefit from the primacy effect in question. ${ }^{102}$

Thus, in the Court's view, when EU institutions exercise their discretion in designating persons to be subjected to sanctions, they must do so in accordance with established principles of EU law safeguarding fundamental rights. Inter alia, they must state the reasons for sanctions to persons targeted, and must provide them with a meaningful and fair hearing to contest their designation. As the decision at hand did not provide these safeguards, it had to be annulled. ${ }^{103}$ In terms of our discussion on norm conflict, the Court was saying that not even an apparent conflict existed. There was no contradiction in requiring EU institutions to provide reasons for a listing and an opportunity to challenge it and the provisions of Resolution 1373.

\section{Specific Methods of Avoidance and Resolution}

The cases presented above either employ or hint at several methods of norm conflict avoidance and resolution in addition to Article 103 of the Charter. As with jus cogens, Article 103 creates incentives for courts to avoid norm conflicts, and even reliance on Article 103 itself, when they can, especially when "constitutional" values are implicated, such as the protection of human rights. Even when a genuine conflict truly exists, as in

\footnotetext{
100. Id. paras. 99-100.

101. Id. paras. 101-102.

102. Id. para. 103 .

103. Id. paras. 160-74.
} 
Al-Jedda, courts will attempt to minimize its impact through interpretative means.

In Kadi, we witnessed both the application of Article 103 and what can be termed the testing of the external validity of a Security Council resolution, i.e., the review of its compatibility with the one body of international law that the Council cannot override, jus cogens. Surely there is no great controversy in saying that a Security Council resolution ordering states to torture suspected terrorists would be void due to a conflict with a peremptory norm. But the Security Council would never adopt such a resolution. States can be subtle, even if, or particularly if they wish to limit the rights of individuals, and the likelihood of states openly adopting norms contrary to jus cogens is nil. We thus learned in Kadi that such review of external validity as exercised by the CFI is of little practical use, as the Council resolution will survive this review even when the court (wrongly) reads the content of jus cogens expansively. ${ }^{104}$ Or, if we take Al-Jedda as an example, if the House wished to review the external validity of Resolution $1546,{ }^{105}$ it could have come to no other conclusion than that the resolution was valid, since the prohibition of preventative detention certainly does not qualify as jus cogens, if for no other fact than that internment is expressly allowed in armed conflict. ${ }^{106}$ It is only if the concept of jus cogens is read so expansively that it is stretched to breaking point that it could be used to invalidate a Security Council resolution. In my view, this neither should nor is likely to happen. ${ }^{107}$

Yet, there is no cogent legal reason to test Security Council decisions solely on their external validity. The Council is not a global sovereign, a prince who is legibus solutus. It is an organ of an international organization and its powers are necessarily limited by that organization's constitutive

104. As ICJ President Higgins recently stated in relation to jus cogens, "[t]he examples [of such norms] are likely, in my view, to be very, very few in number." Rosalyn Higgins, A Babel of Judicial Voices? Ruminations from the Bench, 55 INT'L \& COMP. L. Q. 791, 801 (2006). For a much more expansive take on the role of jus cogens in limiting the Security Council, see Alexander Orakhelashvili, The Impact of Peremptory Norms on the Interpretation and Application of United Nations Security Council Resolutions, 16 EUR. J. INT'L L. 59 (2005).

105. Lord Bingham did indeed briefly mention that Security Council resolutions could not override rules of jus cogens - see R (Al-Jedda) v. Sec'y of State for Def., [2007] UKHL 58, para. 35, 12 December 2007, available at http://www.bailii.org/uk/cases/UKHL/2007/58.html

106. See also Sir Michael Wood, Second Lecture: The Security Council's Powers and their Limits, Lauterpacht Lectures, University of Cambridge, para. 50, Nov. 8, 2006, available at http:// www.lcil.cam.ac.uk/Media/lectures/pdf/2006_hersch_lecture_2.pdf.

107. As one author put it, "one of the major threats posed to the concept of jus cogens is the tendency by some of its most fervent supporters to see it everywhere." Bianchi, supra note 11, at 506. 
instrument, the Charter. ${ }^{108}$ That treaty cannot be plausibly interpreted as granting the Council the power to do whatever it wishes. ${ }^{109}$ There can be no doubt that, as a matter of substantive law, an ultra vires decision of the Council which is contrary to the Charter has no binding force. ${ }^{110}$

Thus, the internal validity of a Council resolution against the Charter can also be tested. When it comes to human rights in particular, a persuasive argument can be made that the Council is Charter-bound to conform to certain human rights norms, not limited just to the norms of jus cogens. A textual argument would be that Article 24(2) of the Charter requires the Council to act "in accordance with the Purposes and Principles of the United Nations," while Article 1(3) provides for "promoting and encouraging respect for human rights and for fundamental freedoms for all without distinction as to race, sex, language, or religion" as one of the purposes of the UN. ${ }^{111}$

The lack of a principled reason for rejecting review of the internal validity of Council decisions does not mean that there are no practical difficulties in doing so. First, the Charter does not specify in any way the human rights that could serve as a check on the Council's power. ${ }^{112}$ Secondly, any review of a Council decision, especially in the context of Chapter VII, would have to be deferential, both as to the Council's determination that a threat to the peace, breach of the peace or act of aggression exist, and as to what measures are appropriate to deal with this situation. Finally, and most importantly, the main problem is not with the substantive position that an ultra vires resolution of the Council is invalid, but with the claim of authority to exercise judicial review. In other words,

108. See Bowett, supra note 45 , at $92-93$ ("[T] they are in accordance with the Charter.").

109. See David Feldman, The Role of Constitutional Principles in Protecting International Peace and Security through International, Supranational and National Legal Institutions, 6 N.Z. J. PUB. \& INT'L L. 1, 9 (2008) ("Even if one regards state sovereignty as being at the heart of the powers of international organisations, there is no reason to assume that a state would consent to an organisation exercising a power so as to compromise the interests of that state or the rights of its nationals and residents if the exercise of the power goes beyond a reasonable reading of the scope of the power. It should therefore be possible to explore the limits to the powers of the UN Security Council by applying ordinary legal principles to establish the scope of the authority conferred by an international instrument such as the UN Charter.").

110. See ILC Study, supra note 1, para. 331 ("Since obligations for Member States of the United Nations can only derive out of such resolutions that are taken within the limits of its powers, decisions ultra vires do not give rise to any obligations to begin with.").

111. See Boyle \& Chinkin, supra note 44, at 230; Dapo Akande, The International Court of Justice and the Security Council: Is There Room for Judicial Control of Decisions of the Political Organs of the United Nations?, 46 INT'L \& COMP. L.Q. 309, 316-17 (1997).

112. See Jared Schott, Chapter VII as Exception: Security Council Action and the Regulative Ideal of Emergency, 6 Nw. U. J. INT'L HUM. RTS. 24, 119-22 (2007). 
the fundamental question is who will be the judge of whether a Security Council resolution is in accordance with the Charter. ${ }^{113}$ The Charter itself does not say that the ICJ or any other court, international or domestic, has the power to do so. On the other hand, the Charter does not say either that the Security Council only and exclusively will be the judge of its own powers. Though Council resolutions cannot be subjected as such to a specific action for annulment, they could still be challenged incidentally, if they are invoked in other judicial proceedings.

This dilemma is of course familiar to any student of constitutionalism. The United States Supreme Court, for example, was faced with the exact same question in Marbury v. Madison. ${ }^{114}$ The Court there asserted its power to review the constitutionality of the acts of the other branches of the U.S. government, without any explicit basis in the Constitution's text. That does not mean that the mere assertion of such a power by the Court was enough to actually establish it - what truly mattered was that this claim to authority was accepted by the other actors concerned, and gradually became an entrenched and uncontested (if not uncontroversial) feature of the system.

The same could eventually happen in the international system, yet that is by no means a certainty. The ICJ or some other court might assert its authority to decide on the validity of Security Council resolution, but that does not mean that this claim will be accepted by states and by the Council. So far, the ICJ in particular has refrained from attempting such a Marbury moment. ${ }^{115}$ In two cases - Lockerbie and Genocide - the parties' arguments presented it with an opportunity to review a Security Council resolution. In both cases the Court gave this opportunity a pass, ${ }^{116}$ though in their individual opinions some judges expressed their views both for and against judicial review. ${ }^{117}$ The closest we have come to Marbury before any international court was in the Tadić case ${ }^{118}$ before the Appeals Chamber of

113. See generally Thomas M. Franck, The "Powers of Appreciation": Who Is the Ultimate Guardian of UN Legality?, 86 AM. J. INT'L L. 519 (1992); Jose E. Alvarez, Judging the Security Council, 90 AM. J. INT'L L. 1 (1996).

114. 5 U.S. (1 Cranch) 137 (1803).

115. See Simon Chesterman, An International Rule of Law?, 56 AM. J. COMP. L. 331, 353-54 (2008).

116. See generally Bernd Martenczuk, The Security Council, the International Court and Judicial Review: What Lessons from Lockerbie?, 10 EUR. J. INT'L L. 517, 521-22 (1999); Alvarez, supra note 113, at n.1.

117. See Lockerbie, supra note 41, 1998 I.C.J. 27 (Judgment of Feb. 27); Application of the Convention on the Prevention and Punishment of the Crime of Genocide (Bosn. \& Herz. v. Serb. \& Mont.), 1993 I.C.J. 3 (Order of Apr. 8); 1993 I.C.J. 325 (Order of Sept. 13).

118. Prosecutor v. Tadić, Case No. IT-94-1, Decision on Defence Motion for Interlocutory Appeal on Jurisdiction (Oct. 2, 1995). 
the International Criminal Tribunal for the former Yugoslavia (ICTY), established by a Chapter VII resolution of the Security Council. In that case, the first decided by the ICTY, the defendant challenged the Tribunal's legality, claiming that the Council did not have the legal power to establish a judicial body. The Trial Chamber held that it did not have jurisdiction to pronounce on the legality of the ICTY's establishment, as it could not review a decision of the Council. ${ }^{119}$ The Appeals Chamber, on the other hand, ruled that as a part of its inherent compétence de la compétence it did have the power to enquire about its own legality, and (unsurprisingly) found that the Council did indeed have the authority under the Charter to establish the ICTY. ${ }^{120}$

Yet, Tadić did not provoke a Marbury moment. The Appeals Chamber was dealing with a very specific issue, a challenge to its own legality. No other court so far has reviewed the internal validity of any Council resolution. Though Tadić remains an important precedent, whether it will be followed remains to be seen. Courts will generally find arguments based on the internal validity of a resolution unattractive, and that especially goes for domestic courts. To take Al-Jedda as an example, if the appellants had actually made such an argument and contested the validity of Resolution 1546, it would still have been most unlikely for national judges to become the avant-garde of international law by assuming for themselves the power to review Chapter VII decisions of the Security Council. Moreover, it should also be noted the review of Council resolutions by domestic, as opposed to international courts, would in essence amount to the review of UN acts by its individual member states. Though in principle unobjectionable, this could still in practical terms potentially spell disaster for the system of collective security established by the Charter. ${ }^{121}$

The possibility that courts will start reviewing decisions of the Council relatively soon is not to be excluded. The more the Council impinges on human rights and the more invasive it becomes, the greater the temptation for the courts will be. ${ }^{122}$ Yet, even if a court was willing to entertain a challenge to the external or internal validity of a Council resolution it would be most unlikely that such a challenge would succeed, because of the very limited scope of jus cogens, the lack of specificity of

119. Id., Decision on the Defence Motion on Jurisdiction in the Trial Chamber of the International Tribunal, $\uparrow 5$ (Aug. 10, 1995).

120. Id., Decision on the Defence Motion for Interlocutory Appeal on Jurisdiction, qף 18-22.

121. See Wood, Second Lecture, supra note 106, para. 64.

122. In a similar vein, see Andrea Bianchi, Assessing the Effectiveness of the UN Security Council's Anti-Terrorism Measures: The Quest for Legitimacy and Cohesion, 17 EUR. J. INT'L L. 881, 912-14 (2006). 
human rights constraints on the Council in the Charter itself, and the large deference that would be due to the Council in any case involving the maintenance of international peace and security. ${ }^{123}$

The review of external validity of Council resolution against jus cogens and the review of their internal validity vis-à-vis the Charter are at the same time tools of both conflict avoidance and of conflict resolution. An apparent conflict between a resolution and some other norm of international law is avoided, because a second conflict between the resolution and either the Charter or jus cogens is resolved in the latter's favor. Now, however, it might be helpful to advance another interpretative mechanism of conflict avoidance. This mechanism has thus far not been explicitly used by courts, though this may change, since it provides more practical avenues for the effective protection of human rights than theories of judicial review.

As we have seen above, some Security Council resolutions use exceptionally broad language. For example, Resolution 1546 at issue in $\mathrm{Al}$ Jedda gave the MNF "the authority to take all necessary measures to contribute to the maintenance of security and stability in Iraq," while Resolution 1244 at issue in Behrami and Saramati authorized "Member States and relevant international organizations to establish the international security presence in Kosovo ... with all necessary means to fulfill its responsibilities." Should Article 103 of the Charter truly apply to these kinds of vague phrases, with the effect of prevailing over contrary treaties and denying individuals some of their basic rights? Should open language such as "all necessary measures" and "all necessary means" be read as encompassing everything and anything that the authorized states might want - say preventative detention without recourse to judicial review - thus trumping the very clear and detailed provisions of human rights treaties, like Article 5(1) of the ECHR? Surely not. It is one thing to say that the phrase "all necessary means" has in practice developed as the appropriate diplomatic euphemism for the use of military force, but it cannot be plausibly read as an absolution from all human rights constraints that do not qualify as jus cogens. ${ }^{124}$ The Charter may give the Council the power to override legally valid treaties, and even custom, but this power is by definition exceptional. If, in other words, the Council truly wishes to derogate from otherwise applicable human rights guarantees, it must do so

123. See also Wood, Second Lecture, supra note 106, para. 6 ("“II]t is difficult to conceive of circumstances arising in practice that could raise serious doubts about the legality of the Council's actions."). But see Matthew Happold, Security Council Resolution 1373 and the Constitution of the United Nations, 16 LEIDEN J. INT'L L. 593, 607 (2003) (arguing that Resolution 1373 is ultra vires).

124. See Liivoja, supra note 34 , at 589. 
clearly and explicitly, and it and its members must consequently bear the political responsibility for such an action.

What I am advocating, therefore, is for the creation of a rebuttable interpretative presumption supported by a clear statement rule - Security Council resolutions should be interpreted as far as possible to be compatible with human rights, as well as with other rules of general international law, in the absence of a clear statement by the Council to the contrary. Such a presumption is warranted by several considerations of policy and principle. First, and most generally, by the presumption against norm conflict in international law. ${ }^{125}$ Second, by the indisputable fact that the Security Council was not created as a global legislator, ${ }^{126}$ a quick and dirty substitute for the ordinary international law-making process via treaty or custom. ${ }^{127}$ It is a body with the singular and extremely important mission of safeguarding international peace and security, but despite its apparent omnipotence and the broad exercise of its powers, as for instance in the quasi-legislative Resolution 1373, its role is limited. The legally binding norms that it may create and to which the Charter grants priority are still conditioned upon that mission of maintenance of peace. ${ }^{128}$ Important as that mission undoubtedly is, it is not a license to the Council to ignore the rest of international law.

Third, reading the Council's resolutions so that they are compatible with states' human rights obligations is consistent with the Council's own statements on the matter. For example, in Resolution 1456 (2003), the Council, working at the level of Ministers of Foreign Affairs, affirmed that "States must ensure that any measure taken to combat terrorism comply with all their obligations under international law ... in particular human rights, refugee, and humanitarian law[.]"129 The Council should not be taken to have departed from a commitment that it has promulgated without clear evidence to the contrary.

125. See generally PAUWELYN, supra note 15 , at 240-44.

126. See generally Michael Fremuth \& Jörn Griebel, On the Security Council as a Legislator: A Blessing or a Curse for the International Community?, 76 NORDIC J. INT'L L. 339, 348-60 (2007); Björn Elberling, The Ultra Vires Character of Legislative Action by the Security Council, 2 INT'L ORG. L. REV. 337, 342-52 (2005).

127. See also Ian Johnstone, Legislation and Adjudication in the UN Security Council: Bringing Down the Deliberative Deficit, 102 AM. J. INT'L. L. 275, 299-300 (2008); BOYLE \& CHINKIN, supra note 44 , at 115 .

128. See also Wood, First Lecture, supra note 4, at paras 23-57.

129. S.C. Res 1456, ๆ 6, U.N. Doc. S/RES/1456 (January 20, 2003). 
Fourth, as important as peace and security are, ${ }^{130}$ they are not a priori any more important than human rights, and vice versa. These rights are not gifts or privileges granted to individuals by generously disposed states, but rights which are inherent in the individuals' own dignity as human beings that cannot easily be sacrificed at the altar of security by overly eager states.

Finally, states to which an authority is given by the Council will naturally tend to interpret that authority broadly, as is the case with preventative detention. There is no indication, for example, that the Council truly wished to authorize unreviewable military detentions in Kosovo by Resolution 1244, as was argued by KFOR member states. A presumption can help curtail this tendency, though it cannot eliminate it altogether.

Interpretative presumptions of this sort are ubiquitous in domestic law and they have a pride of place in the human rights sphere. Perhaps the best examples can be had in the public law of the United Kingdom. Not only is a presumption favoring compatibility of legislation with human rights now laid down by statute, in Section 3 of the Human Rights Act 1998, ${ }^{131}$ but courts have for constitutional reasons applied such presumptions independently of the HRA and the ECHR. As Lord Hoffmann put it,

Parliamentary sovereignty means that Parliament can, if it chooses, legislate contrary to fundamental principles of human rights. The Human Rights Act 1998 will not detract from this power. The constraints upon its exercise by Parliament are ultimately political, not legal. But the principle of legality means that Parliament must squarely confront what it is doing and accept the political cost. Fundamental rights cannot be overridden by general or ambiguous words. This is because there is too great a risk that the full implications of their unqualified meaning may have passed unnoticed in the democratic process. In the absence of express language or necessary implication to the contrary, the courts therefore presume that even the most general words were intended to be subject to the basic rights of the individual. In this way the courts of the United Kingdom, though acknowledging the sovereignty of Parliament, apply principles of constitutionality little different from those which exist in countries where the power of the legislature is expressly limited by a constitutional document. ${ }^{132}$

130. See, e.g., Behrami and Behrami v. France, Saramati v. France, Germany, and Norway, App. Nos. 71412/01, 78166/01, Eur. Ct. H.R., paras. 148-49 (2 May 2007), available through the HUDOC database at http://www.echr.coe.int/echr/en/hudoc (affirming "imperative" aim of the UN of safeguarding international peace and security).

131. On the strength of which see Ghaidan v. Godin-Mendoza, [2004] 2 A.C. 557, paras 42-50 (H.L.) (appeal taken from Eng.) (U.K.).

132. R v. Sec'y of State for the Home Dep't, ex parte Simms and Another, [2000] 2 A.C. 115, 131 (H.L.) (appeal taken from Eng.) (U.K.) (per Lord Hoffmann). 
Note that it has been an axiomatic assumption of English constitutional law that Parliament is sovereign and capable of doing as it pleases with human rights, ${ }^{133}$ but that the interpretative presumption exists notwithstanding Parliamentary sovereignty. ${ }^{134}$ All the more reason to apply such a presumption to the Security Council, which is most certainly not a sovereign in the likeness of Parliament. ${ }^{135}$

Likewise, the High Court of Australia, a country which has no written bill of rights, has held that

The insistence on express authorisation of an abrogation or curtailment of a fundamental right, freedom or immunity must be understood as a requirement for some manifestation or indication that the legislature has not only directed its attention to the question of the abrogation or curtailment of such basic rights, freedoms or immunities but has also determined upon abrogation or curtailment of them. The courts should not impute to the legislature an intention to interfere with fundamental rights. Such an intention must be clearly manifested by unmistakeable and unambiguous language. General words will rarely be sufficient for that purpose if they do not specifically deal with a question because, in the context in which they appear, they will often be ambiguous on the aspect of interference with fundamental rights. ${ }^{136}$

Similarly, in the United States, the Supreme Court recently had the opportunity to decide on the habeas corpus rights of detainees in Guantanamo Bay. Inter alia, it invoked a clear statement rule, holding that "Congress should 'not be presumed to have effected such denial [of habeas corpus relief] absent an unmistakably clear statement... to the contrary." "137

133. See Albert Dicey, An Introduction to the Study of the Law of the Constitution 39-40 (1959) ("The principle of Parliamentary sovereignty means neither more nor less than this, namely, that Parliament . . . has, under the English constitution, the right to make or unmake any law whatever; and, further, that no person or body is recognised by the law of England as having a right to override or set aside the legislation of Parliament.") (footnote omitted).

134. See also R v. Sec'y of State for the Home Dep't, Ex parte Pierson, [1998] A.C. 539, 575 (H.L.) (appeal taken from Eng.) (U.K.) (per Lord Browne-Wilkinson) ("From these authorities, I think the following proposition is established. A power conferred by Parliament in general terms is not to be taken to authorise the doing of acts by the donee of the power which adversely affect the legal rights of the citizen or the basic principles on which the law of the United Kingdom is based unless the statute conferring the power makes it clear that such was the intention of Parliament.").

135. But cf. Macarthys Ltd v. Smith, [1979] I.C.R. 785, 788-89 (explaining that the House of Lords likewise employs a clear statement rule in instances of apparent norm conflict between UK law and EU law, with priority being given to the latter in absence of an express statement of Parliament to the contrary.).

136. Coco v. The Queen (1994) 179 C.L.R. 427, 437 (Austl.) (footnote omitted).

137. Boumediene v. Bush, 128 S.Ct. 2229, 2243 (2008) (citing Hamdan v. Rumsfeld, 548 U.S. 557, 575 (2006)); see also Kent v. Dulles, 357 U.S. 116, 129-30 (1958) (narrowly interpreting a statute relied 
The foregoing discussion should not be taken as a facile application of some domestic law analogy to international law. As well noted, such analogies can be "more misleading than enlightening." "138 In this case, however, the basic ideas are the same. A rebuttable interpretative presumption of this type can clearly be a useful method for avoiding conflicts of norms arising from competing (constitutional) considerations the Charter and peace and security on the one hand, and human rights on the other. ${ }^{139}$ To take the facts of Behrami and Saramati as an example, it would have been much a better tool of avoidance for the European Court than its misguided theory of attribution. Why should, after all, the phrase "all necessary means" be read as authorizing preventative detention without any judicial review? ${ }^{140}$

Al-Jedda, on the other hand, is more difficult. Though the Council again used vague language of authorization, it did tie it to the two letters annexed to Resolution 1546, which did expressly mention internment on security grounds. Thus it could be plausibly asserted that the presumption has been rebutted and that the clear statement rule is satisfied. On the other hand, as we have seen above, the House of Lords nonetheless narrowly interpreted this authorization, in essence reading it as dispensing solely with the exhaustive numeration of grounds of detention in Article 5(1) of the ECHR. Moreover, in her judgment Baroness Hale appeared more than a little troubled with any sort of broad reading of Council authorizations infringing on human rights:

We have been concerned at a more abstract level with attribution to or authorisation by the United Nations. We have devoted little attention to the precise scope of the authorisation. There must still be room for argument about what precisely is covered by the resolution and whether it applies on the facts of this case. Quite how that is to be done remains for decision in the other proceedings. ${ }^{141}$

on by the Executive to refuse issuing a passport to a suspected Communist, finding that Congress can curtail the constitutionally protected right to free movement only if its does so in explicit terms).

138. See Wood, Second Lecture, supra note 106, at para 58 (quoting Sir Elihu Lauterpacht).

139. See also Bianchi, supra note 122, at 916 ("[R]arely would one need to construe human rights obligations as conflicting with SC anti-terror measures. A presumption of consistency of the latter with human rights obligations, and -- one may add -- all the more so with regard to peremptory norms, seems a perfectly viable interpretive tool to guarantee the required degree of consistency of SC resolutions with the international legal order.").

140. See also Feldman, supra note 109, at 9 (arguing that "[w]hen exercising functions that interfere with people's rights, international institutions must expect that a strict interpretation will be applied to their powers.").

141. R (In re Al-Jedda) v. Sec'y of State for Def., [2007] UKHL 58, para 129, available at http:// www.bailii.org/uk/cases/UKHL/2007/58.html. 
In conclusion, a clear statement rule is not a magic bullet. It will not be able to avoid all situations of conflict - for instance, it would have been of little use in Kadi, where the Council made its intentions perfectly clear. It is, however, necessary for channeling through law the great powers that the Security Council rightly has, and advancing the (at the moment undoubtedly aspirational) international rule of law. ${ }^{142}$ If the Council truly intends to derogate from human rights, that intent must be manifested in the language of the resolution, and the reasons for doing should be explained openly, not left to backroom dealings between diplomats. ${ }^{143}$

\section{BASIC ASSUMPTIONS, DUALISM AND EQUIVALENT PROTECTION}

\section{A. In Search for a Rule of Recognition}

Let us now examine what is probably both the easiest and the most drastic form of norm conflict avoidance - dualism. By dualism I simply mean the denial by a court or other relevant actor that two apparently conflicting norms belong to the same legal system, or at the very least to two systems which are functionally integrated. If they do not, they cannot truly conflict. To give an example, if the Security Council passed a resolution requiring all member states to preventatively detain suspected terrorists and deny them judicial review of that detention, that might suffice to displace or qualify the ECHR pursuant to Article 103 of the Charter. It would generally not be enough, however, to dispense with human rights protections granted by domestic constitutional law. ${ }^{144}$ If such a case would ever come before the United States Supreme Court, for instance, it would say that the constitutional guarantee of habeas corpus can only be suspended by Congress in cases of rebellion or invasion, not by an organ of the UN. ${ }^{145}$ Indeed, the Constitutional Court of Bosnia and Herzegovina has already expressly ruled that Article 103 cannot displace domestic constitutional protections, despite the fact that the Constitution of Bosnia

142. See Chesterman, supra note 115 , at $360-61$.

143. See Johnstone, supra note 127, at 305-06 (emphasizing the need for the Council to justify its actions publicly).

144. Article 103 does not even purport to - it speaks only of Charter obligations prevailing over other international agreements. See also Feldman, supra note 109, at 3.

145. Cf. Boumediene v. Bush, 128 S.Ct. 2229, 2243 (2008). Indeed, U.S. courts entertain challenges based on the Due Process Clause of the Constitution in regard of targeted sanctions at issue in Kadi, as they are only concerned with domestic implementing legislation and executive acts, not with UN Security Council resolutions or Sanctions Committee designations, which have no effect in U.S. domestic law. See Daniel S. Meyers, The Transatlantic Divide over the Implementation and Enforcement of Security Council Resolutions, 38 CAL. W. INT'L L.J. 255, 276-82 (2008). 
was actually adopted as a treaty, an annex of the Dayton Peace Accords. ${ }^{146}$ To take a further example, in Al-Jedda the applicants argued before the lower UK courts that the rights enshrined in the Human Rights Act are domestic statutory rights that continue to exist even if their corresponding rights under the ECHR are displaced by Article 103. The lower courts disagreed, finding that these domestic rights mirror the rights in the ECHR, and fail whenever these fail. This issue was not raised on appeal before the House of Lords, which accordingly said nothing on the matter. ${ }^{147}$

Pointing out that domestic law and international law are separate legal systems seems almost trivial, but it is instructive as it exposes some of the basic assumptions that we make when defining what actually constitutes a legal system. For instance, even when a particular municipal legal order is largely open to international law, by making treaties and/or custom part of the law of the land, we understand that international law enters the domestic legal order under the terms and conditions set out by that domestic order. ${ }^{148}$ From the international perspective we also perceive the now some two hundred domestic legal orders as distinct from the international one, not merely as its sub-systems. ${ }^{149}$ Contrary to some remarks of the CFI in Kadi, ${ }^{150}$ international law makes no claim of

146. Milorad Bilbija et al., No. AP-953/05, The Constitutional Ct. of Bosn. \& Herz., paras. 61-76, (8 July 2006), available at http://www.esiweb.org/pdf/esi_news_id_113a.pdf (“Article 103 of the Charter of the United Nations deals only with a sub-set of possible conflicts of laws in public international law, namely conflicts between the obligations of Member States of the United Nations arising under different treaties. It does not attempt (and indeed would be powerless to attempt) to determine the effect of any such conflict on the obligations of the authorities of Member States under their national constitutional or legal orders."). For more on this case and on the negative reaction it inspired from the international High Representative in Bosnia, see Feldman, supra note 109, at 24-29 (Professor Feldman is a judge on the Constitutional Court of Bosnia).

147. See R (In re Al-Jedda) v. Sec'y of State for Def., [2007] UKHL 58, para. 53, available at http://www.bailii.org/uk/cases/UKHL/2007/58.html.

148. See, e.g., ANTONIO CASSESE, InTERnATIONAL LAW 218-19 (2d ed. 2005); see Bundesverfassungsgericht [BVerfG][Federal Constitutional Court] Oct. 10, 2004, docket no. 2 BvR 1481/04, 111 BVerfGE 307, at paras 34-36, translated in http://www.bverfg.de/entscheidungen/ rs20041014 2bvr148104en.html (holding that "[t]he Basic Law is clearly based on the classic idea that the relationship of public international law and domestic law is a relationship between two different legal spheres and that the nature of this relationship can be determined from the viewpoint of domestic law only by domestic law itself ... [The Basic Law] does not seek a submission to non-German acts of sovereignty that is removed from every constitutional limit and control."). Case noted in Saša Beljin, Bundesverfassungsgericht on the Status of the European Convention of Human Rights and ECHR Decisions in the German Legal Order, 1 EUR. CONST. L. REV. 553 (2005).

149. But see Hans Kelsen, Les rapports de système entre le droit interne et le droit international public, 14 RECUEIL DES COURS 227, 289 (1926-IV) (arguing that international law and domestic law form a unitary legal system, where the latter draws validity from the former).

150. See Case T-315/01, Kadi v. Council and Comm'n, 2005 E.C.R. II-3649, II-3712-13 ("From the standpoint of international law, the obligations of the Member States of the United Nations under the Charter of the United Nations clearly prevail over every other obligation of domestic law ....."). 
prevailing over domestic law. International law is not hierarchically superior, but generally indifferent to what domestic law says - even up to the point of treating rules of domestic law as "facts." 151 Thus, it is perfectly normal for us to accept that the same act can be lawful under domestic law but unlawful under international law, or vice versa, ${ }^{152}$ just as an act can be lawful under German law but not under French law. That, not hierarchy, is the import of Article 27 of the VCLT when it states that "[a] party may not invoke the provisions of its internal law as justification for its failure to perform a treaty." 153 Likewise, even when international law does take into account rules of domestic law, it does so on its own terms. For instance, in order to establish whether a particular actor qualifies as an organ of a state, international law will look at the domestic law of that state. It will still, however, attach organ status to an actor even if it is not designated as such by the state's internal law, if the relationship between the state and the actor is of complete control on the one side, and complete dependence on the other. ${ }^{154}$

Distinguishing between domestic law and international law comes easily. However, we have seen the applicants in Kadi argue that a Security Council resolution could not prevail over contrary human rights guarantees in EU law, as EU law is a legal order independent from the Charter and general international law. That dualist or fragmentationist argument failed before the CFI, but has now met with success before the Advocate General of the ECJ and before the ECJ itself.

151. See Certain German Interests in Polish Upper Silesia (F.R.G. v. Pol.), 1926 P.C.I.J. (ser. A) No.7, at 19 (May 25) ("From the standpoint of International Law and of the Court which is its organ, municipal laws are merely facts which express the will and constitute the activities of States, in the same manner as do legal decisions or administrative measures.”)

152. It is true that many or most domestic legal systems employ harmonious interpretation so as to avoid conflicts between domestic law and international law, in absence of the legislature clear intent to the contrary. See, e.g., Murray v. Schooner Charming Betsy, 6 U.S. (2 Cranch) 64, 118 (1804). However, this is not true norm conflict avoidance. What the courts try to avoid are situations in which an action which may be lawful under domestic law puts the state in breach of its international legal obligations. But this canon of interpretation quite clearly assumes that the domestic and international legal systems are separate, as the domestic legislature can indeed pass a valid statute which would be contrary to international law.

153. See Andreas Paulus, Jus Cogens in a Time of Hegemony and Fragmentation, 74 NORDIC J. INT'L L. 297, 319-23 (2005) (explaining that the lack of any hierarchical ambition vis-à-vis domestic law extends even to jus cogens norms of international law).

154. See ILC Articles on State Responsibility, supra note 36, at art. 4(2); Military and Paramilitary Activities in and against Nicaragua (Nicar. v. U.S.), Merits, Judgment, 1986 I.C.J. 14, para. 109 (June 27); Application of the Convention on the Prevention and Punishment of the Crime of Genocide (Bosn. and Herz. v. Serb. and Mont.), Judgment, 2007 I.C.J. 1, paras. 390-95 (February 26). 
In his opinion, Advocate General Maduro ${ }^{155}$ (AG) expressed strong disagreement with the reasoning of the CFI, particularly with its characterization of the relationship between international law and EU law. According to the AG,

[T] he logical starting point of our discussion [of the relationship between international and Community law] should, of course, be the landmark ruling in Van Gend en Loos, in which the Court affirmed the autonomy of the Community legal order. The Court held that the Treaty is not merely an agreement between States, but an agreement between the peoples of Europe. It considered that the Treaty had established a 'new legal order', beholden to, but distinct from the existing legal order of public international law. In other words, the Treaty has created a municipal legal order of trans-national dimensions, of which it forms the 'basic constitutional charter'.

After reviewing the relevant case law of the ECJ, the AG argued that

it would be wrong to conclude that, once the Community is bound by a rule of international law, the Community Courts must bow to that rule with complete acquiescence and apply it unconditionally in the Community legal order. The relationship between international law and the Community legal order is governed by the Community legal order itself, and international law can permeate that legal order only under the conditions set by the constitutional principles of the Community. ${ }^{157}$

The AG could see nothing in the EU and EC treaties that would absolve measures implementing UN Security Council resolutions from the fundamental rights guarantees of the Community legal order. The AG was furthermore not persuaded by the argument of the EU institutions and the United Kingdom (relying on Behrami) that, in similar situations, even the European Court of Human Rights would not exercise jurisdiction. According to the AG,

It is certainly correct to say that, in ensuring the observance of fundamental rights within the Community, the Court of Justice draws inspiration from the case-law of the European Court of Human Rights. None the less, there remain important differences between the two courts. The task of the European Court of Human Rights is to ensure the observance of the commitments entered into by the Contracting States under the Convention. Although the purpose of the Convention is the maintenance and further realisation of human rights and fundamental freedoms of the individual, it is designed to operate primarily as an

155. Case C-402/05 P, Kadi v. Council and Comm'n, Opinion of Advocate General Poiares Maduro (Jan. 16, 2008), available through database search at http://curia.europa.eu/jcms/jcms/ j_6/home.

156. Id. at para. 21 (footnotes omitted).

157. Id. at para. 24 (footnote omitted). 
interstate agreement which creates obligations between the Contracting Parties at the international level. This is illustrated by the Convention's intergovernmental enforcement mechanism. The EC Treaty, by contrast, has founded an autonomous legal order, within which States as well as individuals have immediate rights and obligations. The duty of the Court of Justice is to act as the constitutional court of the municipal legal order that is the Community. The European Court of Human Rights and the Court of Justice are therefore unique as regards their jurisdiction ratione personae and as regards the relationship of their legal system with public international law. Thus, the Council, the Commission and the United Kingdom attempt to draw a parallel precisely where the analogy between the two Courts ends. ${ }^{158}$

The AG proceeded to review the applicant's human rights claim on the merits, finding that there is no reason for any sort of circumscribed review, ${ }^{159}$ and concluded that his right to be heard by EU institutions and his right to effective judicial review were infringed by the impugned regulation, taking into account the lack of a genuine and effective mechanism of judicial control by an independent tribunal at the UN level. $^{160}$

On appeal, the ECJ agreed entirely with the main strands of the AG's reasoning. ${ }^{161}$ It first held that

the Community is based on the rule of law, inasmuch as neither its Member states nor its institutions can avoid review of the conformity of their acts with the basic constitutional charter, the EC Treaty, which established a complete system of legal remedies and procedures designed to enable the Court of Justice to review the legality of acts of the institutions .... It is also to be recalled that an international agreement cannot affect the allocation of powers fixed by the Treaties or, consequently, the autonomy of the Community legal system, observance of which is ensured by the Court by virtue of the exclusive jurisdiction conferred on it by Article 220 EC, jurisdiction that the Court has, moreover, already held to form part of the very foundations of the Community. ${ }^{162}$

Therefore, according to the Court,

obligations imposed by an international agreement cannot have the effect of prejudicing the constitutional principles of the EC Treaty, which include the principle that all Community acts must respect fundamental

158. Id. at para. 37 (footnotes omitted).

159. Id. at paras. 44-46.

160. Id. at paras. 54-55.

161. Joined Cases C-402/05 P \& C-415/05 P, Kadi \& Al Barakaat Int'1 Found. v. Council and Comm'n, Judgment, (Sept. 3, 2008), available through database search at http:/curia.europa.eu/ jcms/jcms/j_6/home.

162. Id. at paras. 281-82 (citations omitted, emphasis added). 
rights, that respect constituting a condition of their lawfulness which it is for the Court to review in the framework of the complete system of legal remedies established by the Treaty. ${ }^{163}$

The ECJ further noted that international law in no way prohibits the judicial review of domestic measures implementing a state's international obligations, including obligations stemming from Chapter VII resolutions of the Security Council. ${ }^{164}$ The Court thus concluded that

the review by the Court of the validity of any Community measure in the light of fundamental rights must be considered to be the expression, in a community based on the rule of law, of a constitutional guarantee stemming from the EC Treaty as an autonomous legal system which is not to be prejudiced by an international agreement. The question of the Court's jurisdiction arises in the context of the internal and autonomous legal order of the Community, within whose ambit the contested regulation falls and in which the Court has jurisdiction to review the validity of Community measures in the light of fundamental rights. ${ }^{165}$

The position of the CFI, on the one hand, and those of the AG and the ECJ, on the other, are worlds apart. The CFI views the EU legal order, though "autonomous," as still essentially an inseparable part of the international legal order. For the AG and the ECJ, the EU legal order is not just autonomous, but also domestic, municipal, and, most importantly, constitutional. ${ }^{166}$ According to the AG and the ECJ, it is Community law that determines how international law operates within it, not the other way around. For them, the annulment of a regulation implementing a Security Council resolution and violating fundamental rights is a purely domestic affair, just as it would be for a United States court to review an implementing statute against the Constitution.

This is a familiar debate. For most international lawyers, EU law might not be "just" regional international law, and is certainly to a large degree self-contained. But it still remains a subsystem of international law, if for no other reason because its founding instruments are treaties concluded between states. ${ }^{167}$ For EU lawyers, on the other hand, these

163. Id. at para. 285 (emphasis added).

164. Id. at paras. 298-99.

165. Id. at paras. 316-17.

166. See Comment by Andreas Paulus, at 13 (Jan. 17, 2008, 17:59 EST), http:// opiniojuris.org/2008/01/16/can-the-security-council-displace-human-rights-treaties-al-jedda-part-2/ (last visited Sept. 5, 2008) (noting the almost magical quality of the AG's use of the word “constitution.").

167. See, e.g., Trevor Hartley, International Law and the Law of the European Union - A Reassessment, 72 BRIT. Y.B. INT'L L.1, 2-3 (2001); Bruno Simma \& Dirk Pulkowski, Of Planets and the Universe: Self-contained Regimes in International Law, 17 EUR. J. INT’L L. 483, 516 (2006); Alain 
treaties are constitutional instruments, which create a new, independent legal order with its own hierarchy of norms. ${ }^{168}$ Why labeling EU law as constitutional should necessarily render it non-international is rarely, if ever, explained. Weiler and Haltern have once persuasively argued that the question whether EU law is constitutional or international law poses a false dichotomy, as it can be both at the same time. ${ }^{169}$ But, for the AG and the ECJ in Kadi at least, and probably EU lawyers generally, ${ }^{170}$ the dichotomy is ultimately neither false nor inconsequential, as the true test for whether EU law is part of international law comes when international law, in the guise of Article 103 of the Charter, claims primacy, and EU (constitutional) law either accepts this claim or refuses to give in. ${ }^{171}$ For EU lawyers, the opinions of the AG and the ECJ are perfectly logical and sensible, but that is only because they assume, and fervently believe, that the EU legal order is independent, municipal and constitutional. For general international lawyers, on the other hand, it is the CFI's judgment that is perfectly logical and sensible, because for them something that is created by treaty, no matter how self-contained, cannot but be a part of a unified, universal international legal order. ${ }^{172}$

Pellet, Les fondements juridiques internationaux du droit communautaire, 5 COLLECTED COURSES OF THE ACADEMY OF EUROPEAN LAW 193, 249 (1994).

168. See, e.g., Nikolaos Lavranos, Judicial Review of UN Sanctions by the Court of First Instance, 11 Eur. ForeIgn AfF. REV. 471, 477-80 (2006); Christina Eckes, Judicial Review of European AntiTerrorism Measures - The Yusuf and Kadi Judgments of the Court of First Instance, 14 EUR. L.J. 74, 82-91 (2008); Bjørn Kunoy, The Jurisdiction of the ECJ to Review the Legality of the Transposition of an International Act in the EC Legal Order, 76 NORDIC J. INT'L L. 19 (2007); Piet Eeckhout, Community Terrorism Listings, Fundamental Rights, and UN Security Council Resolutions. In Search of the Right Fit, 3 EUR. CONST. L. REV. 183 (2007).

169. J.H.H. Weiler \& Ulrich R. Haltern, The Autonomy of the Community Legal Order - Through the Looking Glass, 37 HARV. INT'L. L.J. 411, 417 (1996).

170. Witness, for example, the rave reviews that the AG's opinion received in an editorial of an eminent (constitutional) journal:

[The AG's opinion] made short shrift of the Court's pusillanimity in terrorism cases. In it he drew the full consequences of the Court's own youthful audacity in proclaiming an autonomous legal order, forty-five years ago, in which the rule of law is vindicated. . . We do not know if the Court has the courage to follow him. If so or not, the opinion raises the standard to which, in the great words of George Washington when presiding over the American constitutional convention, the wise and honest may repair.

Editorial, 4 EUR. CONST. L. REV. 1, 5 (2008).

171. Joseph Raz has argued, for example, that a claim to be supreme is a necessary feature of an independent legal system. See JOSEPH RAZ, THE AuthORITY OF LAW: ESSAYS ON LAW AND MORALITY 118-19 (1983).

172. See, e.g., Christian Tomuschat, Case T-306/01, Ahmed Ali Yusuf and Al Barakaat International Foundation v. Council and Commission; Case T-315/01, Yassin Abdullah Kadi v. Council and Commission 43 COMMON MKT. L. REV. 537, 551 (2006), stating that "[t]he Court of First Instance has taken a courageous step forward in acknowledging the primacy of the UN system over the Community legal order. This was certainly not easy for judges who are accustomed to discarding any objections from the domestic level of the 25 Member States as being irrelevant. In principle, the 
It further must be noted just how completely atextual the debate is. In reality it has nothing to do with logic, though it is frequently represented as such, nor is it about the interpretation of a particular provision in this treaty or that, but about the basic assumptions that underlie our thinking about the law and about what constitutes a legal system. It is thus contingent upon perspectives, ideologies and normative agendas. Everybody concerned has their own vision of the international legal order, or their own "constitutional" project, European or global.

Most remarkably for a general international lawyer, neither the AG nor the ECJ in Kadi ever explain what exactly in their view makes the EU legal order distinct and independent from international law. Again, the various EU treaties certainly do not say so. ${ }^{173}$ At best, their argument is conclusory, even solipsistic - we say EU law is constitutional, therefore it is constitutional, and therefore it is not international. These leaps in logic are most evident when the AG and the ECJ struggle to explain why the EU treaties establish an independent, constitutional legal order, while another treaty, the ECHR, that also creates individual and not just inter-state rights, still remains "merely" international and can thus be overridden by the Security Council, as happened in Al-Jedda. ${ }^{174}$

Again, the purpose of this discussion of Kadi is not to demonstrate that either the CFI's or the ECJ's judgment were "wrongly decided," but to show how both the CFI and the AG and ECJ proceeded in their analysis from a different set of basic assumptions about the nature of their legal system. Such assumptions exist in all legal systems, even if they are not written down in a foundational text, and are usually not assessed or discussed, but are considered axiomatic and are relied on as a matter of course.

These assumptions are considered axiomatic, that is, until they are actually challenged and possibly changed when the underlying social or ideological superstructure changes. Fluctuations in these assumptions,

configuration thus attained is a well-balanced construction, suited to foster international cooperation within a homogeneous world order system." Observe also, for example, the confidence with which Pauwelyn asserts that "states can 'contract out' of . . . [some] rules of international law ... but ... [not] out of the system of international law," a proposition that he believes has the status of jus cogens. PAUWELYN, supra note 15, at 37.

173. See Hartley, supra note 167 , at 7-9.

174. See Case C-402/05 P, Kadi v. Council \& Comm'n, Opinion of Advocate General Poiares Maduro, para. 37 (Jan. 16, 2008), available through database search at http:/curia.europa.eu/ jcms/jcms/j_6/home; Joined Cases C-402/05 P \& C-415/05 P, Kadi \& Al Barakaat Int'l Found. v. Council and Comm'n, Judgment, at paras. 316-17 (Sept. 3, 2008), available at http://curia.europa.eu/ jcms/jcms/j_6/home. 
which are in Hartian terms, if you will, a facet of the rule of recognition, ${ }^{175}$ explain how some very fundamental questions can remain unresolved (or are reopened and resolved anew over and over again) even in some very mature legal systems. Thus, for instance, even more than two hundred years after the adoption of the United States Constitution, and despite the fact that the Constitution has at least one explicit provision on the relationship between domestic law and international law in the Supremacy Clause, courts and academics can still have rancorous debates about what counts as a self-executing treaty, whether non-self-executing treaties are the law of the land, ${ }^{176}$ and what is the precise status of customary international law in the United States legal system. ${ }^{177}$

\section{B. Solange and Equivalent Protection}

Back to Kadi, there is no small irony in the AG's and the ECJ's juxtaposition of the constitutional to the international. We may recall that just a few decades ago it was Community law, spearheaded by the ECJ, that claimed direct effect and primacy over the national legal orders of the member states, asserting somewhat arrogantly that it prevailed even over contrary constitutional domestic guarantees of human rights. That claim to supremacy - bolder by far than that of Article 103 of the Charter - could not have succeeded merely on the ECJ's say-so. It depended on whether the member states, through their highest courts, would accept the ECJ's assertion of authority. As is well known, they did, but not unconditionally. In Solange $I^{178}$ the German Constitutional Court held that it has the power to review the compatibility of EC acts and legislation with the German

175. See H.L.A. Hart, The Concept of LAw 100-10 (Penelope A. Bulloch \& Joseph Raz eds., 2d ed. 1994).

176. Cf. Medellín v. Texas, 128 S. Ct. 1346 (2008).

177. See, e.g., Louis Henkin, International Law as Law in the United States, 82 MicH. L. REV. 1555 (1984); Curtis A. Bradley \& Jack L. Goldsmith, Customary International Law as Federal Common Law: A Critique of the Modern Position, 110 HARV. L. ReV. 815 (1997); Gerald L. Neuman, Sense and Nonsense About Customary International Law: A Response to Professors Bradley and Goldsmith, 66 Fordham L. REV. 371 (1997); Michael D. Ramsey, International Law as Nonpreemptive Federal Law, 42 VA. J. INT'L L. 555 (2002); Harold Hongju Koh, International Law as Part of Our Law, 98 AM. J. I'NTL L. 43 (2004); John O. McGinnis \& Ilya Somin, Should International Law Be Part of Our Law?, 59 STAN. L. REV. 1175 (2007). Similar debates on the application of customary international law in the domestic sphere have taken place in the United Kingdom as well, though there is much less controversy there in comparison to the United States. See, e.g., Trendtex Trading Corp. v. Cen. Bank of Nig. [1977] Q.B. 529, 553-54 (C.A.) (per Lord Denning) (discussing the differences between the doctrines of incorporation and transformation in the application of customary international law within the UK legal system); J. G. Collier, Is International Law Really Part of the Law of England?, 39 INT'L \& COMP. L. Q. 924 (1989).

178. Bundesverfassungsgerichts [BVerfG] May 29, 1974, 37 Entscheidungen des Bundesverfassungsgerichts [BverfGE] 271 (F.R.G). 
Constitution, while in Solange $I I^{179}$ it accepted the primacy of EC law in principle, but reserved for itself the power of review if the EC fails to provide at Community level an equivalent protection of human rights to the one enjoyed by individuals at the domestic level. ${ }^{180}$ So long as (so lange) the EC did provide such equivalent protection, the Court would not interfere.

Like Kadi, the Solange saga exposes two problems. On the one hand is the relationship between two legal orders, on the other the conflict of norms belonging to these two legal orders. As we have seen above, a norm conflict can arise only within the same legal system, or within two systems which are functionally integrated. Thus, in Van Gend and Costa v. ENEL the ECJ knocked on the doors of the municipal legal systems. ${ }^{181}$ In Solange and like cases, the municipal courts responded by letting the ECJ and EU law in, on the condition that they behave themselves. Hence we can say that EU law and the municipal legal systems of EU member states are to a large extent integrated legal systems, but they are still distinct because neither draws validity from the other. ${ }^{182}$

In the case of norm conflict between a norm of EU law and a domestic constitutional norm protecting human rights, the ECJ asserted that the former prevails, while domestic constitutional courts opted for the latter. To this day there remains a frequently revisited, unresolved tension in the interaction between the EU legal order and that of its member states, between integration and supremacy of EU law, on the one hand, and fragmentation, spurred by constitutional concerns about democracy, legitimacy and human rights on the other. ${ }^{183}$ This explains why even the

179. Bundesverfassungsgerichts [BVerfG] October 22, 1986, 73 Entscheidungen des Bundesverfassungsgerichts [BverfGE] 339 (F.R.G).

180. See Corte constituzionale [Corte cost.] 27 dec. 1973, n.183, [Foro Italiano] Foro It. 1974, I, 314 (Italy).

181. Case 26/62, N.V. Algemene Transp. - en Expedite Onderneming van Gend \& Loos v. Nederlandse administratie der belastingen (Neth. Inland Revenue Admin.), 1963 E.C.R. 1; Case 6/ 64, Costa v. ENEL, 1964 E.C.R. 585.

182. For a more sophisticated take on the relationship between EU law and the legal systems of its member states, see Julie Dickson, How Many Legal Systems?: Some Puzzles Regarding the Identity Conditions of, and Relations between, Legal Systems in the European Union, Oxford Legal Stud. Res. Paper No. 40/2008 (October 6, 2008), available at http://ssrn.com/abstract=1279612.

183. See, e.g., Chloé Charpy, The Status of (Secondary) Community Law in the French Internal Order: the Recent Case-Law of the Conseil Constitutionnel and the Conseil d'Etat, 3 EuR. CONST. L. REV.436 (2007) (discussing several recent cases before the Conseil constiutitionnel and Conseil d'Etat in France regarding the relationship between French law and EU law, emphasizing French constitutional identity and equivalent protection); Fernando Castillo de la Torre, Tribunal Constitucional (Spanish Constitutional Court), Opinion 1/2004 of 13 December 2004, on the Treaty establishing a Constitution for Europe, 42 COMMON MKT. L. REV. 1169 (2005) (discussing a Spanish Constitutional Court decision denying absolute supremacy to EU law over national constitutional law). 
constitutional courts of new EU member states adopted their own variants of Solange, despite the decades of development regarding the protection of fundamental rights at EU level. ${ }^{184}$ This confrontation is suspended only so long as EU institutions do not start behaving outrageously - in the assessment of domestic constitutional law - regarding human rights. As we have seen above, a similar incentive is at work when courts are reluctant to review the decisions of the UN Security Council.

\section{The ECHR and Equivalent Protection}

The principle of equivalent protection also found its way into the jurisprudence of the European Court of Human Rights in its Bosphorus line of cases. In 1990, the European Commission on Human Rights decided its very first case on equivalent protection, M. \& Co. v. Germany. ${ }^{185}$ It dealt (appropriately enough) with the responsibility of the member states of the European Community for implementing the acts of the Community itself.

The applicant was a company incorporated in Germany that was heavily fined by the EC Commission for antitrust violations. The applicant alleged, inter alia, that when it lodged its appeal against the EC Commission's decision with the ECJ, the ECJ did not comport with the fair trial guarantees in Article 6 of the ECHR. According to the applicant, when Germany transferred its competencies to the EC and enforced such a flawed decision by the EC institutions, it violated its own obligations under the ECHR.

The European Commission remarked that

[T] he Convention does not prohibit a Member State from transferring powers to international organisations. Nonetheless, The Commission recalls that "if a State contracts treaty obligations and subsequently concludes another international agreement which disables it from performing its obligations under the first treaty it will be answerable for any resulting breach of its obligations under the earlier treaty" (cf. $\mathrm{N}^{\circ}$ 235/56, Dec. 10.6.58, Yearbook 2 p. 256 (300)). The Commission

184. See, e.g., the Decision of 8 March 2006 of the Czech Constitutional Court in case No. Pl. US 50/04 Sugar Quotas, published as No. 156/2006 Coll., official English translation available at http://test.concourt.cz/angl_verze/cases.html (holding that EU law must not infringe upon core constitutional principles, and applying the Solange equivalent protection doctrine for the protection of human rights.). Case noted in Jiř́ Zemánek, The Emerging Czech Constitutional Doctrine of European Law, 3 Eur. Const. L. REV. 418 (2007). A similar decision was rendered by the Polish Constitutional Court - noted in Adam Lazowski, Conformity of the Accession Treaty with the Polish Constitution. Decision of 11 May 2005., 3 Eur. Const. L. Rev. 148 (2007). See also Wojciech Sadurski, 'Solange, chapter 3': Constitutional Courts in Central Europe - Democracy - European Union, 14 EUR. L.J. 1 (2008).

185. App. No. 13258/77, 64 Eur. Comm'n H.R. Dec. \& Rep. 138 (1990), available through the HUDOC database at http://www.echr.coe.int/echr/en/hudoc. 
considers that a transfer of powers does not necessarily exclude a State's responsibility under the Convention with regard to the exercise of the transferred powers. Otherwise the guarantees of the Convention could wantonly be limited or excluded and thus be deprived of their peremptory character. The object and purpose of the Convention as an instrument for the protection of individual human beings requires that its provisions be interpreted and applied so as to make its safeguards practical and effective (cf. Eur. Court H.R., Soering judgment of 7 July 1989, Series A no. 161, para. 87). Therefore the transfer of powers to an international organisation is not incompatible with the Convention provided that within that organisation fundamental rights will receive an equivalent protection. ${ }^{186}$

The Commission then noted that the legal system of the European Communities not only secures fundamental rights but also provides for control of their observance. Indeed, the ECJ heard the applicant's case, and found that its right to a fair hearing was not violated on the merits. Moreover,

The Commission has also taken into consideration that it would be contrary to the very idea of transferring powers to an international organisation to hold the member States responsible for examining, in each individual case before issuing a writ of execution for a judgment of the European Court of Justice, whether Article 6 (Art. 6) of the Convention was respected in the underlying proceedings. ${ }^{187}$

Hence, the application was incompatible ratione materiae with the ECHR and declared inadmissible.

The Commission's reasoning is rather laconic. It first notes that a state which concludes a treaty that would conflict with the ECHR would incur responsibility for doing so, and buttresses this conclusion by reference to the ECHR's object and purpose. Then, however, out of thin air the Commission conjures up the principle of equivalent protection. It cites absolutely no support for such a rule, nor does it acknowledge its intellectual debt to the Solange jurisprudence. But more important is how the Commission uses the principle of equivalent protection. In norm conflict terms, it is a method of conflict avoidance through harmonious interpretation. A conflict between the ECHR and the EC treaty is avoided, as the ECHR itself does not prohibit a transfer of powers via treaty to an international organization if that organization provides an equivalent protection of fundamental rights.

So, like in Solange, equivalent protection is used as a mechanism of conflict avoidance. However, M. \& Co. differs from Solange in two 
important respects, as does its progeny. First, there is no doubt in the Commission's mind that the two potentially conflicting norms belong to the same legal system. Both the EC Treaty and the ECHR are treaties governed by public international law - it is just that if a state party to both treaties cannot comply with one of them without violating the other, it will incur state responsibility as it commits a wrongful act under the latter treaty. In Solange, on the other hand, the German Constitutional Court allowed Community law to permeate the distinct domestic sphere, on certain conditions. Second, unlike in Solange, where Community law claimed primacy over domestic law, there was no such claim here. As a matter of international law, neither the EC Treaty nor the ECHR prevail over one another in any hierarchical sense. It is true that the Commission says that a transfer of powers cannot be allowed to deprive the human rights guarantees of the ECHR of their "peremptory character," but that is no more than rhetorical flourish. The Commission cannot be saying that the ECHR as a whole is jus cogens, invalidating any conflicting treaties. Surely, the right to a fair hearing in antitrust cases does not qualify as a peremptory norm by any definition of the term.

Nine years after $M . \& C o$. , the European Court of Human Rights first grappled with the principle of equivalent protection in three cases decided on the same day by its Grand Chamber: Waite and Kennedy v. Germany, ${ }^{188}$ Beer and Regan v. Germany, ${ }^{189}$ and Matthews v. United Kingdom. ${ }^{190}$ The first two cases are for all practical purposes identical, so only Waite and Kennedy will be referred to hereafter. The applicants in that case were two former temporary workers of the European Space Agency (ESA), employed on a project based in Germany. When their contracts were terminated, they tried to contest that decision before German labor courts. The courts denied them relief, on the grounds that the ESA Convention, to which Germany was a party, provided for the immunity of the ESA from domestic jurisdiction. Before the European Court, the applicant claimed that the denial of relief was a violation of their right of access to a court under Article 6 of the ECHR.

The Court was of the opinion that

[w] here States establish international organisations in order to pursue or strengthen their cooperation in certain fields of activities, and where they

188. App. No. 26083/94, 30 Eur. Ct. H.R. 261 (1999), available through the HUDOC database at http://www.echr.coe.int/echr/en/hudoc.

189. App. No. 28934/95, Eur. Ct. H.R. (1999), available through the HUDOC database at http:// www.echr.coe.int/echr/en/hudoc.

190. App. No. 24833/94, 28 Eur. Ct. H.R. 361 (1999), available through the HUDOC database at http://www.echr.coe.int/echr/en/hudoc. 
attribute to these organisations certain competences and accord them immunities, there may be implications as to the protection of fundamental rights. It would be incompatible with the purpose and object of the Convention, however, if the Contracting States were thereby absolved from their responsibility under the Convention in relation to the field of activity covered by such attribution. ... For the Court, a material factor in determining whether granting ESA immunity from German jurisdiction is permissible under the Convention is whether the applicants had available to them reasonable alternative means to protect effectively their rights under the Convention. ${ }^{191}$

The ESA did provide such alternative means, through an administrative appeals board. Moreover,

bearing in mind the legitimate aim of immunities of international organisations ... the test of proportionality cannot be applied in such a way as to compel an international organisation to submit itself to national litigation in relation to employment conditions prescribed under national labour law. To read Article $6 \S 1$ of the Convention and its guarantee of access to court as necessarily requiring the application of national legislation in such matters would, in the Court's view, thwart the proper functioning of international organisations and run counter to the current trend towards extending and strengthening international cooperation. ${ }^{192}$

Therefore, the Court found Germany's grant of immunity to the ESA to be proportionate under Article 6 and within its margin of appreciation. ${ }^{193}$

As in $M . \&$ Co., the Court was faced with an apparent or potential norm conflict, this time between the ESA Convention and the ECHR. And, again as in $M . \& C o$., the Court interpreted the ECHR narrowly, by saying that if the ESA provided "reasonable alternative means" for protecting the applicants' rights, a restriction on their access to German courts was proportionate.

The Matthews case was significantly different - not only was a norm conflict not avoidable through equivalent protection, it was also unresolvable. The applicant in that case was a citizen of Gibraltar, an overseas territory of the United Kingdom, who was denied the opportunity to vote for the European Parliament. Namely, a 1976 Act of the European Council, agreed upon by all EC member states and having treaty status, withheld the franchise for EC parliamentary elections from the people of Gibraltar, as it prescribed in its Annex II that "[ $\mathrm{t}]$ he United Kingdom will

191. Waite \& Kennedy v. Germany, 30 Eur. Ct. H.R. at paras. 67-68, available through the HUDOC database at http://www.echr.coe.int/echr/en/hudoc.

192. Id. at para. 72 .

193. Id. at para. 73 . 
apply the provisions of this Act only in respect of the United Kingdom," thus excluding its dependencies and overseas territories ${ }^{194}$ (mainly due to a long-standing bilateral dispute between Spain and the UK on the status of Gibraltar). The applicant alleged a breach of Article 3 of Protocol No. 1 to the ECHR, which provides that " $[\mathrm{t}] \mathrm{he}$ High Contracting Parties undertake to hold free elections at reasonable intervals by secret ballot, under conditions which will ensure the free expression of the opinion of the people in the choice of the legislature."

The Court first reasoned as follows:

In the present case, the alleged violation of the Convention flows from an annex to the 1976 Act, entered into by the United Kingdom, together with the extension to the European Parliament's competences brought about by the Maastricht Treaty. The Council Decision and the 1976 Act (see paragraph 18 above), and the Maastricht Treaty, with its changes to the EEC Treaty, all constituted international instruments which were freely entered into by the United Kingdom. Indeed, the 1976 Act cannot be challenged before the European Court of Justice for the very reason that it is not a "normal" act of the Community, but is a treaty within the Community legal order. The Maastricht Treaty, too, is not an act of the Community, but a treaty by which a revision of the EEC Treaty was brought about. The United Kingdom, together with all the other parties to the Maastricht Treaty, is responsible ratione materiae under Article 1 of the Convention and, in particular, under Article 3 of Protocol No. 1, for the consequences of that Treaty.

In determining to what extent the United Kingdom is responsible for "securing" the rights in Article 3 of Protocol No. 1 in respect of elections to the European Parliament in Gibraltar, the Court recalls that the Convention is intended to guarantee rights that are not theoretical or illusory, but practical and effective .... It is uncontested that legislation emanating from the legislative process of the European Community affects the population of Gibraltar in the same way as legislation which enters the domestic legal order exclusively via the House of Assembly. To this extent, there is no difference between European and domestic legislation, and no reason why the United Kingdom should not be required to "secure" the rights in Article 3 of Protocol No. 1 in respect of European legislation, in the same way as those rights are required to be "secured" in respect of purely domestic legislation. In particular, the suggestion that the United Kingdom may not have effective control over the state of affairs complained of cannot affect the position, as the United Kingdom's responsibility derives from its having entered into treaty commitments subsequent to the applicability of Article 3 of Protocol No. 1 to Gibraltar, namely the Maastricht Treaty taken together with its obligations under the Council Decision and the 1976 Act. Further, the

194. Matthews v. United Kingdom, App. No. 24833/94, Eur. Ct. H.R. paras. 17-18 (18 February 1999), available through the HUDOC database at http://www.echr.coe.int/echr/en/hudoc. 
Court notes that on acceding to the EC Treaty, the United Kingdom chose, by virtue of Article 227(4) of the Treaty, to have substantial areas of EC legislation applied to Gibraltar ....

The Court then found that "no reason has been made out which could justify excluding the European Parliament from the ambit of the elections referred to in Article 3 of Protocol No. 1 on the ground that it is a supranational, rather than a purely domestic, representative organ."196 Moreover, the competences of the European Parliament indicated that it could be considered as a part of Gibraltar's legislature within the meaning of Article 3 of Protocol No. 1, which was thus fully applicable. ${ }^{197}$ Hence, as the citizens of Gibraltar were completely denied the right to vote at the elections for the European Parliament, the Court found a violation of Article 3 of Protocol No. 1. ${ }^{198}$

For the European Court in Matthews, a norm conflict was genuine and could not be avoided. On the one hand, the ECHR required the United Kingdom to allow elections for the European Parliament in Gibraltar. On the other, the United Kingdom was prohibited from allowing such elections by another treaty, the 1976 Act. In such a situation, the European Court did the only thing that it could by ruling that the United Kingdom could not escape its responsibility under the ECHR by honoring another treaty commitment, which it entered into freely. Moreover, because the ECJ could not review the 1976 Act on human rights grounds as it had treaty status within the EC legal order, the principle of equivalent protection could not be used to avoid the norm conflict.

Matthews is a fascinating case for two more reasons. First, not only was the norm conflict unavoidable, it was also unresolvable. Even if the European Court possessed some sort of general subject-matter jurisdiction as does the ICJ, it could not give formal priority either to the ECHR or to the 1976 Act. Both of these instruments were valid, legally binding treaties, and no rule of conflict resolution could have been used to invalidate or prioritize either. ${ }^{199}$ In essence, no judicial body could ever resolve such a conflict,

\footnotetext{
195. Id. at paras. 33-34.

196. Id. at para. 36 .

197. Id. at paras. 45-54.

198. Id. at paras. 64-65.

199. Specifically, the conflict rules in Art. 30 of the VCLT are completely useless in a case like Matthews. First, the ECHR and the 1976 Act can hardly be said to be treaties relating to the same subject matter, rendering Art. 30 inapplicable from the very start. But even if this (admittedly entirely arbitrary) criterion is to be interpreted expansively, as suggested by the ILC - see ILC Study, supra note 1, para. 254 - the conflict rules in Art. 30 would work no better. The application of lex posterior is to an extent hindered by the temporal dimension of the norm conflict that will be explored below. More importantly, lex posterior cannot be applied simply because the parties to the two treaties were not
} 
which can only have a political solution. ${ }^{200}$ Solely the states which created such a conflict by concluding two contradictory treaties could put it at rest, ${ }^{201}$ and that, as we shall see presently, is exactly what they did.

The second intriguing aspect of the norm conflict in Matthews is its temporal dimension. As was noted by dissenting Judges Freeland and Jungwiert, at the time of its adoption, the 1976 Act was not incompatible with the ECHR, as the EC Assembly (as it then was) could on no view be regarded as a "legislature" within the meaning of Article 3 of Protocol No. 1 to the ECHR. ${ }^{202}$ Indeed, it was accepted by the majority that it was the 1992 Maastricht Treaty that upgraded, as it were, the European Parliament's status to a proper legislature, and only this made Article 3 of Protocol No. 1 applicable. ${ }^{203}$ There was thus a period of almost twenty years in which the two norms coexisted, but did not conflict.

The political solution to the norm conflict was found when Spain agreed not to object to the United Kingdom's extension of the franchise to Gibraltar, as it understood that the United Kingdom was trying to implement its ECHR obligations and a binding decision of the European Court of Human Rights. ${ }^{204}$ However, when the United Kingdom passed the European Parliament (Representation) Act 2003 (EPRA), Spain did not want to give the UK an entirely free pass, since in its view the UK, inter alia, improperly included Gibraltar within one of its preexisting electoral districts in England and Wales instead of giving it a distinct status. Spain thus initiated an interstate action before the ECJ challenging the EPRA's compatibility with the 1976 Act. In its defense, the UK argued that the Annex to the 1976 Act should be interpreted as far as possible to be compatible with the ECHR and that it should not be a bar to it extending the franchise to Gibraltar via EPRA. Moreover, though Gibraltar was for electoral purposes incorporated into an electoral district within England, it

identical, as required by Art. 30(3). But even if the parties were identical - say if the membership of the Council of Europe and the EU was at the time one and the same - there is absolutely no indication that the parties to the latter treaty had any intention of modifying the ECHR. If anything, they thought that they were acting consistently with the ECHR. Lex posterior, which is by its nature a presumption about states' intent (see Borgen, supra note 29, at 587), cannot be used to produce results that states cannot possibly have intended.

200. See PAUWELYN, supra note 15 , at 418-22.

201. See, Hartley, supra note 167 , at 30-35.

202. Matthews v. United Kingdom, App. No. 24833/94, Eur. Ct. H.R. para. 9 (18 February 1999), available through the HUDOC database at http://www.echr.coe.int/echr/en/hudoc (Freeland, J. and Jungwiert, J. dissenting on the grounds that even in 1999 the European Parliament would not qualify as a "legislature" within the meaning of Article 3 of Protocol No. 1 to the ECHR).

203. Id. paras. 33-34.

204. See Case C-145/04, Spain v. United Kingdom, 2006 E.C.R. I-07917, I-7924 (reproducing the text of the declaration of the two governments). 
did not thereby become, under domestic law, a part of the United Kingdom. ${ }^{205}$

The ECJ agreed with the UK's argument and held that even though the Annex to the 1976 Act continued to be in force, it should not be interpreted as preventing the extension of the franchise, as mandated by the ECHR. ${ }^{206}$ In other words, the ECJ retroactively interpreted the 1976 Act to make it compatible with Article 3 of Protocol No. 1 to the ECHR, even though after Matthews was decided everyone involved thought that it was incompatible. Thus, we can bear witness to the extraordinary narrative of two norms, the ECHR and the 1976 Act. These treaties textually did not change at all in their thirty years of coexistence, which were for the better part of these thirty years thought not to conflict, then suddenly did conflict because of the Treaty of Maastricht. Then that judicially unresolvable conflict seemed to have ended through a negotiated deal, only for the ECJ to say that there was no conflict in the first place.

Let us now turn to the latest, and perhaps most instructive European Court case on equivalent protection, Bosphorus Airways v. Ireland, which is unlike Matthews a most successful example of norm conflict avoidance. ${ }^{207}$ From 1991 onward, the UN Security Council was enacting measures in relation to the conflict in the former Yugoslavia, including a variety of sanctions against the Federal Republic of Yugoslavia (FRY). On 17 April 1993, the Security Council adopted Resolution 820 (1993), providing that states should impound, inter alia, all aircraft in their territories "in which a majority or controlling interest is held by a person or undertaking in or operating" from the FRY. That Resolution was implemented in Community law by EC Regulation 990/93. ${ }^{208}$ The applicant was a Turkish airline charter company, which leased a plane from JAT, the FRY's airline. When the plane landed in Ireland for repairs, it was impounded by the Irish authorities on the basis of the EC Regulation. As the plane was leased from and not operated by JAT, the Irish authorities asked the Sanctions Committee of the Security Council for an opinion on whether the plane was covered by the Council's sanctions regime, and got an affirmative answer. ${ }^{209}$ The applicant challenged the impounding decision before Irish courts, which referred the question whether the EC regulation

205. Id. at I-7939 to I-7940.

206. Id. at I-7940 to I-7942.

207. Bosphorus Hava Yolları Turizm ve Ticaret Anonim Şirketi v. Ir., App. No. 45036/98, 2005VII Eur. Ct. H. R. 109, 42 E.H.R.R 1 (30 June 2005), available through the HUDOC database at http:// www.echr.coe.int/echr/en/hudoc.

208. Id. para. 16 .

209. Id. paras. 21-22. 
applied to an aircraft leased from JAT to the ECJ. The ECJ found that it did, and that the restrictions on the applicant's right to enjoy its property were justified on the account of public interest, as their purpose was to secure international peace and security. ${ }^{210}$

Before the European Court of Human Rights, the applicant maintained that the manner in which Ireland implemented the sanctions regime to impound its aircraft amounted to a violation of Article 1 of Protocol No. 1 to the ECHR, which protects the right to property. ${ }^{211}$ For its part, the respondent government argued that it was merely enforcing a binding regulation of the EC, in which it had no discretion of its own. According to the government, so long as the EC provided equivalent protection of human rights to that of the ECHR, Ireland could not bear responsibility for implementing its EC obligations. ${ }^{212}$

The Court first remarked that the legal basis for impounding the aircraft was undoubtedly the EC regulation. Moreover, according to the Court,

It is true that the Regulation (EEC) no. 990/93 originated in a UNSC resolution adopted under Chapter VII of the United Nations Charter (a point developed in some detail by the Government and certain third parties). While the resolution was pertinent to the interpretation of the regulation, the resolution did not form part of Irish domestic law and could not therefore have constituted a legal basis for the impoundment of the aircraft by the Minister for Transport.

Accordingly, the Irish authorities rightly considered themselves obliged to impound any departing aircraft to which they considered Article 8 of Regulation (EEC) no. 990/93 applied. Their decision that it did so apply was later confirmed, in particular, by the ECJ. ${ }^{213}$

The Court then found that "the impugned interference was not the result of an exercise of discretion by the Irish authorities, either under Community or Irish law, but rather amounted to compliance by the Irish State with its legal obligations flowing from Community law and, in particular, Article 8 of Regulation (EEC) no. 990/93."214 Furthermore, to assess the applicant's claim on the merits, the Court held that it had to enquire whether there was "a reasonable relationship of proportionality

210. Case C-84/95, Bosphorus Hava Yollari Turizm ve Ticaret AS v. Minister for Transp., Energy and Comm'ns, Ir. and the Attorney Gen., 1996 E.C.R. I-3953.

211. Bosphorus Hava Yolları Turizm ve Ticaret Anonim Şirketi v. Ir., App. No. 45036/98, 2005VII Eur. Ct. H.R. para. 107, 42 E.H.R.R 1 (30 June 2005), available through the HUDOC database at http://www.echr.coe.int/echr/en/hudoc.

212. Id. paras. 109-10.

213. Id. para. 145 (citations omitted).

214. Id. para. 148. 
between the means employed and the aim sought to be realised," in other words "whether a fair balance has been struck between the demands of the general interest in this respect and the interest of the individual company concerned." 215 Hence,

the Court has recognised that absolving Contracting States completely from their Convention responsibility in the areas covered by such a transfer would be incompatible with the purpose and object of the Convention; the guarantees of the Convention could be limited or excluded at will thereby depriving it of its peremptory character and undermining the practical and effective nature of its safeguards. The State is considered to retain Convention liability in respect of treaty commitments subsequent to the entry into force of the Convention.

In the Court's view, State action taken in compliance with such legal obligations is justified as long as the relevant organisation is considered to protect fundamental rights, as regards both the substantive guarantees offered and the mechanisms controlling their observance, in a manner which can be considered at least equivalent to that for which the Convention provides. By "equivalent" the Court means "comparable"; any requirement that the organisation's protection be "identical" could run counter to the interest of international co-operation pursued. However, any such finding of equivalence could not be final and would be susceptible to review in the light of any relevant change in fundamental rights protection. ${ }^{216}$

Moreover, according to the Court,

If such equivalent protection is considered to be provided by the organisation, the presumption will be that a State has not departed from the requirements of the Convention when it does no more than implement legal obligations flowing from its membership of the organisation.

However, any such presumption can be rebutted if, in the circumstances of a particular case, it is considered that the protection of Convention rights was manifestly deficient. In such cases, the interest of international co-operation would be outweighed by the Convention's role as a "constitutional instrument of European public order" in the field of human rights.

It remains the case that a State would be fully responsible under the Convention for all acts falling outside its strict international legal obligations. $^{217}$

As, in the Court's view, the "impugned measure constituted solely compliance by Ireland with its legal obligations flowing from membership

215. Id. para. 149.

216. Id. paras. 154-55 (citations omitted).

217. Id. paras. 156-57 (citations omitted). 
of the European Community," ${ }^{218}$ and as the EC institutions, most of all the $\mathrm{ECJ}$, do provide an equivalent protection of fundamental rights to that of the ECHR system, "the presumption arises that Ireland did not depart from the requirements of the Convention when it implemented legal obligations flowing from its membership of the European Community." ${ }^{219}$ The Court considered it clear that "there was no dysfunction of the mechanisms of control of the observance of Convention rights" within the EC legal system and that "it cannot be said that the protection of the applicant company's Convention rights was manifestly deficient." 220 Consequently the presumption was not rebutted, ${ }^{221}$ and the applicant's claim was rejected.

Let us now cast Bosphorus in the terms of our enquiry into norm conflict. First, the principle of equivalent protection under the ECHR is applicable only when a state "does no more than implement legal obligations" it assumed under some other treaty, in other words, when it has no independent discretion. ${ }^{222}$ As we have seen above, discretion was also instrumental for the CFI when it distinguished the OMPI case from Kadi. If discretion exists under a norm laid down either in an EC regulation or in a Security Council resolution, it does not truly conflict with an ECHR obligation. Thus, if there was no norm conflict in Bosphorus because Ireland had discretion as to whether to impound the aircraft or not, the applicant's claim would have been assessed on its merits like any other.

Second, if there is no such discretion and an apparent norm conflict exists, a presumption will arise that there is no norm conflict with the ECHR if the treaty arrangement in question provides, as a general matter, an equivalent protection of human rights. ${ }^{223}$ In the Court's view, that presumption is very strong - it can only be rebutted if the protection of human rights was shown to be manifestly deficient in the circumstances of that particular case. ${ }^{224}$ Indeed, in their joint concurring opinion in Bosphorus several judges disagreed with the majority precisely on whether the presumption should be so strict, or whether a looser standard than

218. Id. para. 158.

219. Id. para. 165 (citations omitted).

220. Id. para. 166 .

221. Id.

222. Id. para. 156 .

223. Id. paras. 154-55. Contra Waite and Kennedy v. Germany, App. NO. 26083/94, 30 Eur. Ct. H.R. 261 (18 February 1999), available through the HUDOC database at http:// www.echr.coe.int/echr/en/hudoc (interpreting solely Article 6 of the ECHR as not being infringed if the international organization to which the state has given immunity provides reasonable alternatives to judicial review).

224. Bosphorus Hava Yolları Turizm ve Ticaret Anonim Şirketi v. Ir., App. No. 45036/98, 2005VII Eur. Ct. H. R. 109, 42 E.H.R.R. 1, para. 156, available through the HUDOC database at http://www.echr.coe.int/echr/en/hudoc. 
"manifestly deficient" protection should be employed. ${ }^{225}$ For our present purposes, it is immaterial whether the presumption should be stronger or weaker, or indeed whether it should have been employed at all by the Court. $^{226}$ The important thing is that it was. As we have seen above, such interpretative presumptions, where a norm - in this case that of the ECHR - is interpreted narrowly so as not to conflict with other norms - are an omnipresent method of avoiding norm conflict.

Third, it must be realized that the outcome of the presumption being rebutted and of the Court finding in favor of the applicant on the merits of his claim would have been an unresolvable norm conflict. In Bosphorus, such a norm conflict would exist between the ECHR on the one hand, and the EC Treaty, requiring Ireland to comply with an EC regulation, on the other. Again, no legal rule could resolve such a genuine conflict - it could only have a political solution in the repeal or amendment of either of the conflicting norms (though, of course, a repeal of an EC regulation would politically be a far more likely outcome than an amendment to the ECHR).

Finally, despite the fact that it was dealing with an EC regulation implementing a Security Council resolution, no hierarchy argument based on Article 103 of the Charter was made in Bosphorus. As the Court took great pains to make clear, the case was framed in such a way that an apparent norm conflict existed solely between the ECHR and EU law, not between the ECHR and a UN Security Council resolution. ${ }^{227}$ The plane was impounded on the basis of the regulation, not the resolution, as the resolution did not form a part of Irish domestic law while the regulation did have direct effect. ${ }^{228}$ Moreover, as we have seen above, an argument based on hierarchy was not made in any of the equivalent protection cases under

225. Id. (Rozakis, Tulkens, Traja, Botoucharova, Zagrebelsky and Garlicki, joint concurrence).

226. See generally Steve Peers, Limited Responsibility of European Union Member States for Actions within the Scope of Community Law, 2 EUR. CONST. L. REV. 443 (2006) (criticizing the holding of Bosphorus Airways v. Ireland for applying the presumption that no norm conflict exists with the ECHR if there is an equal protection of human rights provided by the treaty arrangement); Sionaidh Douglas-Scott, Bosphorus Hava Yollari Turizm Ve Ticaret Anonim Sirketi v. Ireland, 43 COMMON MKT. L. REV. 243 (2006) (addressing the interaction between the EU and the European Court of Human Rights through the lens of Bosphorus); Cathryn Costello, The Bosphorus Ruling of the European Court of Human Rights: Fundamental Rights and Blurred Boundaries in Europe, 6 HUM. RTS. L. REV. 87 (2006) (analyzing the doctrine of "equivalent protection" as used in the Bosphorus case).

227. See also Christina Eckes, Does the European Court of Human Rights Provide Protection from the European Community? - The Case of Bosphorus Airways, 13 EuR. PUB. L. 47, 61 (2007), ("The only clear conclusion is that the Court consciously did not mention the Security Council resolution. By doing so, it successfully got around taking an open stand on the hierarchy between UN law and the Convention.")

228. Bosphorus Hava Yolları Turizm ve Ticaret Anonim Şirketi v. Ir., App. No. 45036/98, 2005VII Eur. Ct. H.R. 109, 42 E.H.R.R 1, paras. 35, 145, available through the HUDOC database at http:// www.echr.coe.int/echr/en/hudoc. 
the ECHR. This is a crucial distinction between these cases and Solange. But now, let us turn to the last of the problems regarding equivalent protection that will be discussed here: whether the doctrine could indeed be applied in cases where a hierarchy argument is made, such as Kadi and $\mathrm{Al}$ Jedda.

\section{Article 103 of the Charter and Equivalent Protection}

In Kadi, the AG concluded his opinion by mentioning something quite a bit like the equivalent protection doctrine:

Had there been a genuine and effective mechanism of judicial control by an independent tribunal at the level of the United Nations, then this might have released the Community from the obligation to provide for judicial control of implementing measures that apply within the Community legal order. However, no such mechanism currently exists. As the Commission and the Council themselves have stressed in their pleadings, the decision whether or not to remove a person from the United Nations sanctions list remains within the full discretion of the Sanctions Committee - a diplomatic organ. In those circumstances, it must be held that the right to judicial review by an independent tribunal has not been secured at the level of the United Nations. As a consequence, the Community institutions cannot dispense with proper judicial review proceedings when implementing the Security Council resolutions in question within the Community legal order. ${ }^{229}$

With this paragraph, the equivalent protections story, started in Solange when the German Constitutional Court resisted the ECJ's assertion that EC law trumps domestic constitutional law, even its guarantees of human rights, came to a full circle with the AG using the exact same rationale to protect human rights guaranteed by EC law against the intrusion of the Security Council. But make no mistake - the equivalent protection doctrine was not a major part of the AG's opinion. Note that he says that equivalent protection at the UN level might have released the EC from its obligation of providing judicial review, not that it would. Moreover, his entire reasoning is based on the view that the UN Charter and Security Council resolutions have no direct effect in EU/EC law, just as they have no such effect in Irish, English or German law. As the two norms as such conceptually cannot conflict, equivalent protection is simply not relevant as a tool of conflict avoidance. ${ }^{230}$

229. Case C-402/05 P, Kadi v. Council and Comm'n, Opinion of Advocate General Poiares Maduro, para. 54 (Jan. 16, 2008), available through database search at http://curia.europa.eu/ jcms/jcms/j_6/home.

230. Contra Joined Cases C-402/05 P \& C-415/05 P, Kadi \& Al Barakaat Int'1 Found. v. Council and 
On the other hand, in Behrami and Al-Jedda there was (in principle) no dispute that the ECHR and the UN Charter belong to the same international legal system, and thus could directly conflict with one another. Bosphorus-based arguments on equivalent protection thus figured prominently in the parties' arguments in both cases. ${ }^{231}$ However, in Behrami the European Court held that the impugned actions were not attributable to the respondent states, but to the UN. Hence, the Court was able to distinguish Bosphorus simply on the account that the respondent states had no conflicting obligations. ${ }^{232}$ In Al-Jedda, on the other hand, the House of Lords did not address the interveners' equivalent protection argument.

So, what of it? Were their Lordships mistaken in not so doing? Had, moreover, the European Court properly decided the attribution issue in Behrami, should it have applied its Bosphorus reasoning to organizations like KFOR empowered by Security Council resolutions, or to the UN itself?

These questions have no easy answer. What is clear, however, is that the application of the equivalent protection doctrine to a Security Council resolution would go well beyond the Court's reasoning in Bosphorus. Though it is true that Bosphorus also concerned a UN sanctions regime, the norm conflict in that case was not between a Security Council resolution and the ECHR, but between an EC regulation (and consequently the EC Treaty) and the ECHR. Again, none of the equivalent protection cases before the European Court dealt with a norm which claimed that it prevailed over the ECHR, as a Security Council resolution would under Article 103 of the Charter. If there truly is a (quasi-)hierarchical relationship between two norms, the lower-ranked norm by definition

Comm'n, Judgment, paras. 318-26 (Sept. 3, 2008), available through database search at http:// curia.europa.eu/jcms/jcms/j_6/home.

231. See, e.g., Behrami and Behrami v. France, Saramati v. France, Germany, and Norway, App. Nos. 71412/01, 78166/01, Eur. Ct. H.R., para. 80 (2 May 2007), available through the HUDOC database at http://www.echr.coe.int/echr/en/hudoc (arguing that "the Convention permitted States to transfer sovereign power to an international organisation to pursue common goals if it was necessary to comply with international legal obligations and if the organisation imposing the obligation provided substantive and procedural protection "equivalent" to that of the Convention (Bosphorus, cited above, para. 155): neither NATO nor KFOR provided such protection.”). See also R (In re Al-Jedda) v. Sec'y of State for Def., [2007] UKHL 58, [2008] 1 A.C. 332 (appeal taken from Eng.), available at http://www.bailii.org/uk/cases/UKHL/2007/58.html.

232. Behrami, App. Nos. 71412/01\& 78166/01, Eur. Ct. H.R. para. 151. See also Guglielmo Verdirame, Breaches of the European Convention on Human Rights Resulting from the Conduct of International Organisations, EUR. HuM. RTS. L. REV. 209, 212-13 (2008) (arguing that the Court's distinguishing of Bosphorus was unpersuasive). 
cannot set any conditions on the application of the higher-ranked norm, even if that condition is the equivalent protection of human rights.

Barring review of the internal and external validity of the relevant Security Council resolution that could avoid the norm conflict with the ECHR altogether, the only way for an equivalent protection condition to be imposed on a resolution would be for the European Court to say that it is not enough that the Charter claims to prevail, but that the ECHR must also accept this claim, as national constitutional courts did in their Solange jurisprudence in relation to EU law. Now, a general international lawyer might say that this would be quite obviously wrong - again, if one can talk about these things as right or wrong - as the hierarchical import of Article 103 is generally accepted by states in their mutual relations, as well as in Article 30(1) of the VCLT. This does not change the fact, however, that many human rights lawyers in particular would be very tempted by this argument. $^{233}$ The principal goal of the human rights movement has always been to limit the power of the state over the individual, even if the state is fully democratic, representative and legitimate. Here, suddenly, general international law (and lawyers) are saying that human rights should kowtow to the UN Security Council, an organ comprised of fifteen states which, no matter how important its mission, is not accountable to anyone.

This tension is quite visible in the cases that we have examined. As we have seen, the European Court of Human Rights's attribution reasoning in Behrami is best explained by a reluctance to address the respondent states' Article 103 argument that Resolution 1244 prevailed over Article 5 of the ECHR. Further hints include the Court's frequent remarks about the ECHR's special role as the "constitutional instrument of European public order,"234 and, naturally, the Court's own special role as the guardian of that order. Even in Al-Jedda, where a domestic court accepted that Charter obligations prevailed over the ECHR by virtue of Article 103, Baroness Hale made the remarkable observation that

It would be so much simpler if the European Convention on Human Rights had contained a general provision to the effect that the rights guaranteed [therein] are qualified to the extent required or authorised by United Nations resolutions. $^{235}$

233. See, e.g., IAIn CAMERon, Council of Europe Report, The European Convention on Human Rights, Due Process and United Nations SECurity COUNCIL COUNTER-Terrorism SANCTIONS, (2006), http://www.coe.int/t/f/affaires_juridiques/coop\%E9ration_juridique/droit_ international_public/Textes_\&_documents/2006/I.\%20Cameron\%20Report\%2006.pdf (arguing that there is no obstacle in applying Bosphorus to the $\mathrm{UN}$ ).

234. Behrami, App. Nos. 71412/01 \& 78166/01 para. 145 (quoting Bosphorus Hava Yolları Turizm ve Ticaret Anonim Şirketi v. Ir., App. No. 45036/98, 2005-VII Eur. Ct. H. R. 109, 42 EHRR 1).

235. Al-Jedda, para. 125. 
It would indeed be much simpler if such a provision existed. It would also be entirely unnecessary if the Charter, as opposed to the ECHR, was seen as the constitutional or foundational instrument of a single legal order. $^{236}$ It is only if this legal order is fragmented that the Charter's authority must not only be asserted, but also accepted in other, supposedly self-contained treaties.

Thus, the application of the equivalent protection doctrine to Security Council resolutions would be a major departure from Bosphorus. It would also be significantly different from Solange, which was a conditional surrender of independence by the undoubtedly distinct national legal orders to Community law, which remain distinct precisely because the surrender was conditional. ${ }^{237}$ Applying equivalent protection in cases like Behrami and Al-Jedda, on the other hand, would amount to a conditional declaration of independence of the ECHR from general international law.

It is certainly true that at present the European Court of Human Rights is not prepared to hold that the UN Charter and its organs have no business in saying whether the ECHR applies. Even in Behrami the Court recalled that

the principles underlying the Convention cannot be interpreted and applied in a vacuum. [The Court] must also take into account relevant rules of international law when examining questions concerning its jurisdiction and, consequently, determine State responsibility in conformity and harmony with the governing principles of international law of which it forms part, although it must remain mindful of the Convention's special character as a human rights treaty. ${ }^{238}$

However, Lord Rodger's view in Al-Jedda that it is "hard to imagine that . . . the [European] Court would readily fail to give effect to articles 25 and 103 of the Charter" ${ }^{\text {"239 }}$ should also be taken with a few grains of salt. The Court is not there yet, but whether it will give in to its fragmentationist impulse depends primarily on how big of a threat it perceives the Security Council to be to the "constitutional" European public order protecting human rights.

236. See, e.g., Shelton, supra note 21, at 164 (stating that Article 103 of the Charter "has been taken to suggest that the aims and purposes of the United Nations - maintenance of peace and security and promotion and protection of human rights - constitute an international public order to which other treaty regimes and the international organizations giving effect to them must conform.").

237. See Dickson, supra note 182, at 10-11 (considering the legal theory that EU Member States' legal systems remain distinct and free to determine the position of other normative systems in relation to domestic laws); Raz, supra note 171, at 118 (identifying legal systems' claimed supremacy).

238. Behrami para. 122 (emphasis added).

239. Al-Jedda para. 116. 


\section{CONCLUSION}

If there is one thing that the cases presented above demonstrate, it is that courts generally do what they can to avoid norm conflicts. The most common are the instances of harmonious interpretation used in numerous cases before the European Court, such as Al-Adsani, ${ }^{240}$ Prince of Liechtenstein ${ }^{241}$ and Maumousseau. ${ }^{242}$ To these we can add the equivalent protection cases in their intra-systemic, purely conflict avoiding variant, as represented by Bosphorus, as opposed to their inter-systemic, Solange variant, which presupposes the existence of two separate legal systems.

Rarer are the cases where norm conflict is genuine and unavoidable. Rarer still are those situations in which norm conflict is both unavoidable and unresolvable. The paradigmatic case is of course Matthews, but there are others, old and new. For example, the famous Soering case ${ }^{243}$ could be taken as an example of an unresolvable conflict between the nonrefoulement component of Article 3 of the ECHR and a valid extradition treaty which recognized no such exception. ${ }^{244}$ Likewise, if the applicant's argument in Al-Jedda that Article 103 of the Charter does not apply to Security Council authorizations had been accepted by the House of Lords, there would still have been a valid Chapter VII resolution conflicting with the equally valid ECHR. Similarly, had the Court in Waite and Kennedy not interpreted Article 6 of the ECHR consistently with the practice of states to give immunity to international organizations, there would have

240. Al-Adsani v. United Kingdom, App. No. 35763/97, Eur. Ct. H.R. (21 November 2001), available through the HUDOC database at http://www.echr.coe.int/echr/en/hudoc (holding that the jus cogens prohibition of torture did not conflict with the law of state immunity). See also Jones v. Ministry of Interior of Saudi Arabia, [2006] UKHL 26, [2007] 1 A.C. 270, 298 (appeal taken from Eng.).

241. Prince Hans-Adam II of Liechtenstein v. Germany, App. No. 42527/98, Eur. Ct. H.R., (27 June 2001), available through the HUDOC database at http://www.echr.coe.int/echr/en/hudoc (holding that the right of access to court in Article 6 of the ECHR did not conflict with the Convention on the Settlement of Matters Arising out of the War and the Occupation, prohibiting German courts to entertain claims arising out of confiscations of German property in the name of reparations for damages in World War II).

242. Maumousseau and Washington v. Fr., App. No. 39388/05, Eur. Ct. H.R. (6 December 2007), available through the HUDOC database at http://www.echr.coe.int/echr/en/hudoc (holding that the ECHR does not conflict with the Hague Convention on the Civil Aspects of International Child Abduction).

243. Soering v. U.K, 161 Eur. Ct. H.R. (ser. A) (7 July 1989), available through the HUDOC database at http://www.echr.coe.int/echr/en/hudoc (holding that under Article 3 of the ECHR a state cannot extradite a person to another state where that person is at a substantial risk of being subjected to cruel or inhuman treatment of punishment).

244. See Tobias Thienel, Can the Security Council Displace Human Rights Treaties? (Al-Jedda, Part 2), OPINIO JURIS, Sept. 5, 2009, http://opiniojuris.org/2008/01/16/can-the-security-councildisplace-human-rights-treaties-al-jedda-part-2/ (discussing the implications of the Al-Jedda holding). 
been an unresolvable norm conflict between the ECHR and the ESA Convention.

Perhaps the most important insights from examining the practicalities of norm conflict can be gained in relation to Article 103 of the Charter. There the tension between the integrationist commitment to general international law and the potentially fragmentationist commitment to human rights is the most palpable. Even the most dedicated adherent of the UN Charter can appreciate the potential for abuse inherent in the Security Council's wide discretion. That discretion might or might not get reviewed by courts in the future. More importantly, it can be curtailed through the use of interpretative presumptions, without stretching the relationship between general international law and human rights to a breaking point. There is nothing extravagant or earth-shattering in requiring the Council to derogate from human rights clearly and unambiguously if and when it wishes to do so. If such a request is good enough for democratically elected legislatures such as Congress or Parliament, surely it must be good enough for the Security Council.

Being as it is a claim to primacy on behalf of the Charter, Article 103 also neatly exposes the various normative constitutionalist agendas at play, the first one being the less than persuasive idea that the Charter itself is a constitution, and that international law as a whole is a constitutional legal order. ${ }^{245}$ On the other end of the spectrum are the undisputedly distinct, constitutional domestic legal orders of states. Not even the most die-hard generalist international lawyer (except, perhaps, those of the more extreme Kelsenian stripe) would argue that Security Council resolutions, or domestic statutes implementing such resolutions, would prevail over domestic constitutional protections within that municipal legal order.

But what of those constitutional projects somewhere in the middle of the spectrum, such as those of the ECHR or the EU? As we have seen, the European Court of Human Rights has shown much unease in Behrami regarding the argument that the Security Council can prevail over the ECHR, in its view the "constitutional instrument of European public order," while at the same time expressing its sentiment that the ECHR is indeed a part of international law. On the other hand is the ECJ's insistence in Kadi that EU law is a constitutional legal order, independent from the $\mathrm{UN}$ and international law. What makes one a more plausible constitution

245. See generally Christian Tomuschat, International Law: Ensuring the Survival of Mankind on the Eve of a New Century, 281 RECUEIL DES COURS (1999); Bernhardt, supra note 38. But see Jean d'Aspremont \& Frédéric Dopagne, Two Constitutionalisms in Europe: Pursuing an Articulation of the European and International Legal Orders, 69 HEIDELBERG J. OF INT'L L. (ZAÖRV) (forthcoming, 2009) (identifying some of the weaknesses of this international constitution project). 
than the other, and how can one even try answering this question without committing to an agenda?

That the very concept of a "constitution" is completely undefined when it is used by either of these courts only exacerbates the problem. The word "constitution" can be used to emphasize the importance of a document that embodies the fundamental values of a community, or a polity. "Constitution" can also be used as a value-neutral term for an instrument that sets up organs and institutions and divides their relationships, powers and competencies. In both of these senses the EU could certainly be said to have a constitution, and at that one which has for the most part worked remarkably well and in accord with the distinct, yet integrated legal orders of its member states.

However, "constitution" can also have an additional meaning, that of law that recognizes no source of superior law, that does not draw validity and legitimacy from any other legal order. ${ }^{246}$ This "constitution" is the one which is of interest to us here, and as we have seen above, this "constitution" is truly nothing more than an assumption. The sheer audacity of that assumption is perhaps more evident in regard of the ECHR (where it is in any case made with much less conviction), than in regard of the EU, if for no other reason than because the process (and the project) of emancipation of EU law from international law has been going on for decades, thereby adding to its plausibility. Nonetheless, it still remains an assumption, as is evident from the rather spectacular failure of, to use Joseph Weiler's phrase, that mongrel document that was the Constitutional Treaty, ${ }^{247}$ and indeed from the very fact that the great constitutional moments of the EU always expose its roots in an international treaty, requiring ratification by all of its member states. ${ }^{248}$

It is thus hard to see the bemusement on the part of many EU lawyers when their law is still treated as a sub-species of international law, either by international lawyers, ${ }^{249}$ or by domestic constitutional lawyers ${ }^{250}$ as anything other than a defensive reflex. Those who do not share the overriding devotion to the constitutionalization of the EU as a legal order beholden to no other are simply not persuaded by references to the self-

246. See, e.g., Hartley, supra note 167, at 3-4 (defining different uses of the word "constitution").

247. J.H.H. Weiler, Editorial: Marking the Anniversary of the Universal Declaration; The Irish No and the Lisbon Treaty, 19 EUR. J. INT'L L. 647, 652 (2008).

248. Id. at 650,652 .

249. See Hartley, supra note 167, at 35 (concluding that EC lawyers are reluctant to accept the application of international law in Community Law).

250. See, e.g., Bundesverfassungsgericht [BVerfGE] October 12, 1993, 89 Entscheidungen des Bundesverfassungsgerichts [BVerfGE] 155 (F.R.G.), 33 I.L.M. 395 (1994). 
serving jurisprudence of the ECJ as evidence that this constitutionalization has actually happened. Unless those who employ it - eminent courts included - are prepared to openly defend their agendas and assumptions, constitution-speak is nothing but gratuitous.

In that regard, general international lawyers must equally realize that justifying the primacy of the Charter simply on the basis that Article 103 says so might not be reason enough for courts and lawyers who have a commitment to some other system, especially if they perceive that system as somehow being constitutional in character. ${ }^{251}$ If one shares the generalist agenda, as the present author does - and it must be said that the universality or general applicability of international law is nonetheless just that, an agenda, a project, if perhaps one less ambitious than the various constitutional ones out there - then it must also be acknowledged that it is quite naïve to think that general international law will always prevail over fragmentationist impulses, or even that it should prevail simply by virtue of being general, or because the Charter says so, or that there is a clearly correct position. In the final analysis, the debate about fragmentation has always been about competing political, ideological and institutional interests, not about coherence in the abstract. ${ }^{252}$ General international law will thus prevail only if it accommodates, as far as possible, the concerns of these other actors, be they "constitutional" or not. ${ }^{253}$ If pushed hard enough by the Security Council, for example, even the European Court of Human Rights will be sorely tempted to declare independence from general international law. In accordance with one of the persistent themes of this article, such a conflict can and should be avoided.

251. See Koskenniemi \& Leino, supra note 5, at 559 (arguing that "[e]ven as Article 103may seem like a constitutional provision, few would confidently use it to uphold the primacy of Security Council decisions over, for example, human rights treaties.").

252. See id. at 578 .

253. See Weil, supra note 8, at 419 ("After all, international law has always had "the object of assuring the co-existence of different interests which are worthy of legal protection." (quoting Max Huber)). 